\title{
Immobilizing and Removal of Cadmium and Rhodamine B from an Aqueous System by Converting Solid Waste from Poland; Studies of Equilibrium and Kinetic Sorption
}

\author{
Eleonora Sočo*, Jan Kalembkiewicz \\ Department of Inorganic and Analytical Chemistry, Faculty of Chemistry, Rzeszów University of Technology, \\ Rzeszów, Poland
}

Received: 8 July 2019

Accepted: 8 October 2019

\begin{abstract}
The presented work introduces the chemical modification of coal fly ash (FA) treated with $\mathrm{NaOH}$ and hexadecyltrimethylammonium bromide (HDTMABr) used as adsorbent for the removal of cadmium(II) ions and rhodamine $\mathrm{B}(\mathrm{RB})$ from aqueous solution. The FTIR spectrum shows the presence of organic and inorganic entities that are also seen on the XRD chart. The SEM analysis shows clearly the surface morphology and roughness of FA-HDTMABr. The effect of $\mathrm{pH}$ on adsorption equilibrium was studied. Maximum adsorption was found for $\mathrm{pH}$ values of 9 . The $\mathrm{Cd}(\mathrm{II})$ ions and $\mathrm{RB}$ dye sorption is attributed to different mechanisms of the ion-exchange processes as well as to the adsorption. On the basis of reduced chi-square test $\left(\chi^{2} / \mathrm{DoF}\right)$ values obtained for both sorbates of the considered isotherms, the fitting degree follows the immediate sequence: Langmuir $>$ Jovanović $>$ Redlich-Peterson $>$ Tóth $>$ Freundl ich $>$ generalized Langmiur-Freundlich $>$ extended Jovanović $>$ Halsey $>$ Temkin $>$ Dubinin-Radushkevich $>$ Fumkin-Fowler-Guggenheim $>$ Fowler-Guggenheim-Jovanović-Freundlich $>$ Brunauer Emmett and Teller. The maximum monolayer adsorption capacity of the FA-HDTMABr was found to be $744 \mathrm{mg} \cdot \mathrm{g}^{-1}$ and $666 \mathrm{mg} \cdot \mathrm{g}^{-1}$ for $\mathrm{Cd}(\mathrm{II})$ and $\mathrm{RB}$, respectively. The PFO, PSO, Elovich mass transfer, liquid film diffusion and intra-particle diffusion models were analysed. The PSO model $\left(\mathrm{R}^{2}=0.996\right)$ was slightly lower for $\mathrm{Cd}$ than those of the PFO model $\left(R^{2}<0.7\right)$, which is an indication that the PSO model was better than the PFO model. Purification water containing direct $\mathrm{Cd}$ and RB was made with $94 \%$ efficiency after 1 hour. We found that the chemical enhancement of FA from coal combustion by HDTMABr treatment yields an effective and economically feasible material for the treatment of basic dye and $\mathrm{Cd}(\mathrm{II})$ ions containing effluents.
\end{abstract}

Keywords: fly ash, solid waste, dye-metal system, HDTMABr, adsorption

*e-mail: eleonora@prz.edu.pl 


\section{Introduction}

Highly coloured wastewater containing hazardous dyes and heavy metals is another serious environmental problem [1-3]. Dyes can be classified as anionic (direct, acid, and reactive dyes), cationic (basic dyes) or non-ionic (disperse dyes) [4]. Synthetic dyes are being increasingly used in textile industries, dye manufacturing industries, paper and pulp mills, tanneries, electroplating factories, food companies, etc. [5]. In general, dyes are stable to light, heat and oxidizing agents, and are usually nonbiodegradable. Most dyes are considered to be nonoxidizable substances in traditional biological and physical treatments [6]. Therefore, it is necessary to study the adsorption phenomena of the other class of dyes. Rhodamine B (RB) is a highly water-soluble, basic red dye of the xanthene class [3]. It is a typical cationic dye that has been widely used as a colorant in textile products [7]. The most visible effect of wastewater discharge from the textile industry is incrustation, which reduces light penetration into the water and can adversely affect marine life [7,8]. Rhodamine $\mathrm{B}$ is used as the active medium in pulsed and continuous wave lasers, as a staining fluorescent dye in biology, and as a tracer dye to track the movement of water. Rhodamine B in aqueous solution exists as optically active protonated and zwitterionic forms and colourless lactone form [8]. Cadmium exerts toxic effects on the kidney, the skeletal and the respiratory systems, and is classified as a human carcinogen [9]. Cadmium is known to get accumulated in the liver and changes to the constitution of the bone and blood [10]. Consumption of rice containing high concentrations of cadmium led to a surge in the Itai-Itai disease in Japan in 1955. Cadmium can travel long distances from the source of emission by atmospheric transfer. Human exposure occurs mainly from consumption of contaminated food, active and passive inhalation of tobacco smoke, and inhalation by workers in the nonferrous metal industry [9].

Coal fly ash (FA) is particulate material produced from coal-fired heat and power plants. Large quantities of ash are stored in a slag heap. Ash contamination poses a serious threat to the environment. Contamination during disposal of fly ash, as well as interaction of fly ash and heavy metals in the environment, is very limited. Fly ashes are applied, among others, in the production of building materials, embankment construction and land reclamation. Although a considerable portion of fly ash is used in industries like construction or soil amendments, there is still a large portion that is disposed of directly to the environment. Such disposal is not economically or environmentally sound. In recent years, research interest has increased in terms of the production of low-cost alternatives to activated carbon, which remains an expensive material in spite of its prolific use. Commercially activated carbon is regarded as the most effective adsorbent for controlling organic and inorganic contaminants. Adsorption with coal fly ash may prove to be much cheaper than that with activated carbon. Coal fly ash has potential use in wastewater treatment because of its major chemical components, which are alumina, silica, ferric oxide, calcium oxide, magnesium oxide, and carbon, and its physical properties such as porosity, particle size distribution, and surface area. Hence, fly ash and its fly ash-modified can be promising candidate materials, as an adsorbent and ion exchanger in water and wastewater treatment. The purpose of this research was threefold: firstly, to understand the properties of the new adsorbent such as chemically modified coal fly ash treated with surfactant solution of hexadecyltrimethylammonium bromide (HDTMABr) in reducing $\mathrm{Cd}(\mathrm{II})$ ion and $\mathrm{RB}$ dye concentrations, secondly, to gain insight into the adsorption mechanism of this chemically modified coal fly ash product, and thirdly, to describe the important topic for future studies of the multi-component sorption and utilization of solid waste to simultaneous immobilization of $\mathrm{Cd}(\mathrm{II})$ ion and RB dye. Importantly, the effect of $\mathrm{pH}$, initial concentration of sorbate, and the time of the sorption process of cadmium and rhodamine B by FA-HDTMABr was explored, and the key physical and chemical characteristics of the product were described.

\section{Experimental}

\section{Apparatus}

The rhodamine B concentration in solution was analysed spectrophotometrically by means of a UV-VIS spectrophotometer (JASCO, type V-670, Japan). The cadmium concentration in extracts was determined by flame atomic absorption spectrometer (FAAS, model SavantAA, GBC Scientific Equipment, Australia). Determination of non-metal $(\mathrm{C}, \mathrm{H}, \mathrm{N}, \mathrm{S})$ in the sample was carried out by an EA 1108 elemental analyser (Carlo Erba, Italy). The crystallographic structure of the FA, FA-NaOH and FA-HDTMABr were characterized by x-ray diffraction (XRD), which was carried out on a D2 Phaser (Bruker, Germany) x-ray diffractometer using $\mathrm{Cu}-\mathrm{K} \alpha$ radiation and measuring angle $(2 \Theta)$ from 5 to $65^{\circ}$ and scanning rate of $0.02^{\circ} \mathrm{s}^{-1}$ at $30 \mathrm{kV}$ and $10 \mathrm{~mA}$. The morphology of FA/FA-NaOH/ FAHDTMABr was observed by scanning electron microscopy (SEM). The SEM micrographs were obtained using VEGA 3 (Tescan, USA). The chemical structures of coal fly ash samples were performed by infrared spectroscopy applying Fourier Transformation (FT-IR) on an Alpha (Bruker, Germany). The investigated adsorbents 4000 to $400 \mathrm{~cm}^{-1}$ at a resolution of $0.7 \mathrm{~cm}^{-1}$. FT-IR measurements were made on samples suspended in $\mathrm{KBr}$ discs. 


\section{Materials and Methods}

Sample of Coal Fly Ash (FA)

In this experiment we used high-temperature fly ash produced by the thermal Rzeszów-Załęże power plant in Poland. According to the American Society for Testing Materials (ASTM C618-05), the ash used in this study can be classified as group $\mathrm{F}$, which has pozzolanic properties characterized by $\mathrm{SiO}_{2}+\mathrm{Al}_{2} \mathrm{O}_{3}+\mathrm{Fe}_{2} \mathrm{O}_{3}>70 \%$ and $\mathrm{CaO}<10 \%$.

\section{Preparation of the Modified-Coal Fly Ash Sample}

The coal fly ash treated with $\mathrm{NaOH}$ form (FA$\mathrm{NaOH}$ ) was performed as follows: the fly ash was treated with a $2 \mathrm{M}$ solution of $\mathrm{NaOH}$ at a solutionto-fly-ash-ratio of 10:1 by weight. The sample of adsorbent mass was placed into a round-bottomed flask closed reflux condenser and was put in solution. Suspension of fly ash was then mixed for 6 hours at $100^{\circ} \mathrm{C}$. Obtained $\mathrm{FA}-\mathrm{NaOH}$ was decanted, filtered and repeatedly washed with distilled water until the $\mathrm{pH}$ of filtrate dropped to the $\mathrm{pH}$ of distilled water. Next, the FA-NaOH was dried in an electric dryer at $105^{\circ} \mathrm{C}$ for 24 hours. After first modification, the $100 \mathrm{~g}$ FA-NaOH was placed in a beaker and then saturated with an aqueous solution of surfactant (HDTMABr). The suspension was mixed for 24 hours at $20^{\circ} \mathrm{C}$. In the next step, the solution was filtered, washed several times with distilled water and solid residue dried at $90^{\circ} \mathrm{C}$ for 8 hours to obtain surfactant-modified fly ash (FA-HDTMABr). The amount of HDTMA ${ }^{+}$corresponds to full cation exchange capacity $\mathrm{CEC}$. This $\mathrm{CEC}$ value was determined by $\mathrm{HDTMA}^{+}$adsorption, which was carried out on $2 \mathrm{~g}$ FA- $\mathrm{NaOH}$ with $25 \mathrm{~mL}$ surfactant solution at varied concentrations ranging between $1 \cdot 10^{-3}-8 \cdot 10^{-3} \mathrm{~mol} \cdot \mathrm{L}^{-1}$. Based on the content of non-metal in the solid samples determination, the difference in the contents of carbon, hydrogen and nitrogen between FA-NaOH and that treated with surfactant was used to calculate CEC $\left(0.12 \mathrm{~mol} \mathrm{HDTMA}^{+} / 1 \mathrm{~kg}\right.$ of FA- $\left.\mathrm{NaOH}\right)$ [11].

Reaction of the FA with $\mathrm{NaOH}$ :

$$
\mathrm{Al}, \mathrm{Si}-\mathrm{OH}+\mathrm{NaOH} \rightarrow \mathrm{Al}, \mathrm{Si}_{-} \mathrm{O}^{-} \mathrm{Na}^{+}+\mathrm{H}_{2} \mathrm{O}
$$

Reaction of the FA-NaOH with HDTMABr:

$$
\mathrm{Al}, \mathrm{Si}_{-} \mathrm{O}^{-} \mathrm{Na}^{+}+\mathrm{HDTMA}^{+} \mathrm{Br}^{-} \rightarrow
$$$$
\mathrm{Al}, \mathrm{Si}_{-} \mathrm{O}^{-} \mathrm{HDTMA}^{+}+\mathrm{NaBr}
$$

A maximum value of the sorbed $\mathrm{HDTMA}^{+}$on FA- $\mathrm{NaOH}$ was achieved in initial solution $\mathrm{HDTMA}^{+}$ concentrations higher than $5 \cdot 10^{-3} \mathrm{~mol} \cdot \mathrm{L}^{-1}$. Thus, in solutions of $5 \cdot 10^{-3} \mathrm{~mol} \cdot \mathrm{L}^{-1}$ and $8 \cdot 10^{-3} \mathrm{~mol} \cdot \mathrm{L}^{-1}$, $\mathrm{HDTMA}^{+}$ was sorbed on $\mathrm{FA}-\mathrm{NaOH}$ in the amount of 0.10 and $0.12 \mathrm{~mol} \mathrm{HDTMA}^{+} / 1 \mathrm{~kg}$ of FA-NaOH, respectively.

\section{Rhodamine B and Cd(II) Ions}

We used rhodamine $\mathrm{B}$ (RB), which is also known as [9-(2-carboxyphenyl)-6-diethylamino3-xanthenylidene]-diethylammonium chloride<smiles>CCC1CCC2C(C1)CC(C(C)CC)CC2C1CCCCC1CC</smiles>

The calibrant solutions containing $0.0,0.5,1.0,1.5$ and $2.0 \mathrm{mg} \mathrm{L}^{-1} \mathrm{Cd}(\mathrm{II})$ ions were prepared by diluting stock solution of $1000 \mathrm{mg} \mathrm{L}^{-1} \mathrm{Cd}(\mathrm{II})$ for concentrations of $\mathrm{Cd}$ (II) ions determined by the FAAS method.

\section{Statistical Analysis}

In order to quantitatively compare the applications of each model, the coefficients of determination $\left(\mathrm{R}^{2}\right)$ and a reduced chi-square test $\left(\chi^{2} / \mathrm{DoF}\right)$ were calculated [13]. The linear and non-linear regression (reduced chi-square) value was calculated by using Origin Pro 7.5 software:

$$
X^{2} / D o F=\frac{1}{D o F} \sum_{i=1}^{N} \frac{\left(q_{e i}-q_{e i, m}\right)^{2}}{q_{e i, m}}
$$

...where DoF, $\mathrm{q}_{\mathrm{ei}}$ and $\mathrm{q}_{\mathrm{e}, \mathrm{m}}$ are degrees of freedom, experimental data and model data. The error bars in the line graph represent a confidence interval of $\mathrm{t}$-distribution; the significance was set at $\mathrm{p}=95 \%$ and $\mathrm{n}=3$.

\section{Results and Discussion}

\section{Crystallography, Morphology and Chemical Structure Studies of FA, FA-NaOH and FA-HDTMA}

The XRD study was carried out to understand the crystalline phases of the FA. The x-ray diffractogram of FA is shown in Fig. 1-1a). The various peaks confirm the presence of minerals like quartz, mullite, magnetite and hematite $[11,14]$. The main peaks of quartz were found at $2 \Theta$ value of $20.8862,26.5912$ and 50.3040; mullite was identified at 16.4036, 25.9896 and 40.8538; and kaolinite at 26.2225. Moreover, the FA also contain trace amounts of magnetite at 29.3855 and 30.9573 . The XRD pattern of the FA- $\mathrm{NaOH}$ showed that the amounts of mineral in the FA-NaOH were decreased from the FA, as observed in the reduction of these peak intensities (Fig. 1-1b). We also observed the appearance of zeolites, which were $\mathrm{NaX}$ and sodalite. This observation indicated the conversion of fly ash into zeolite-like material under alkaline conditions. Previous 
(1) XRD patterns

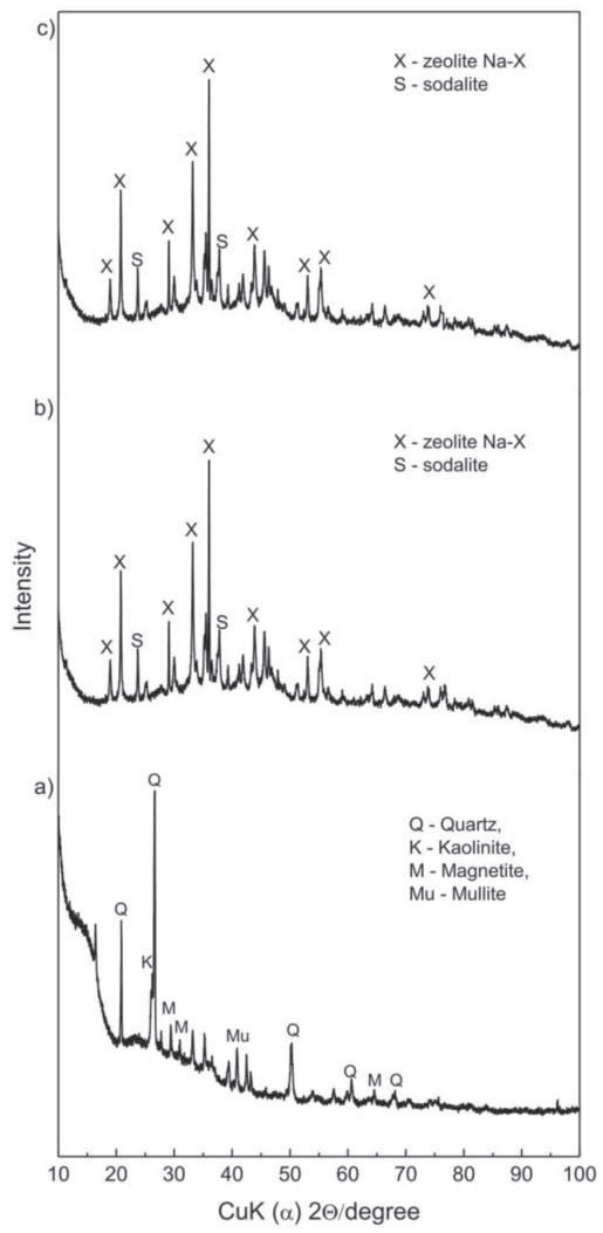

(2) SEM images
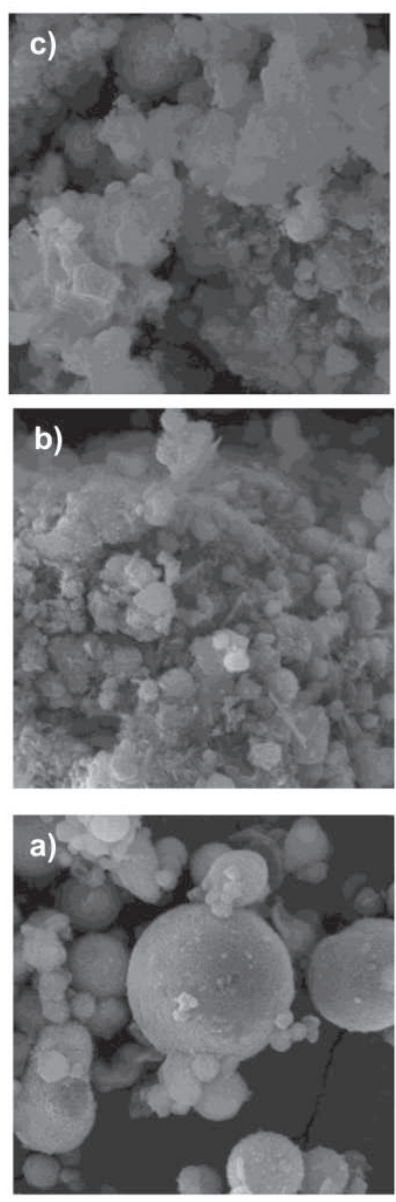

(3) FT-IR spectra

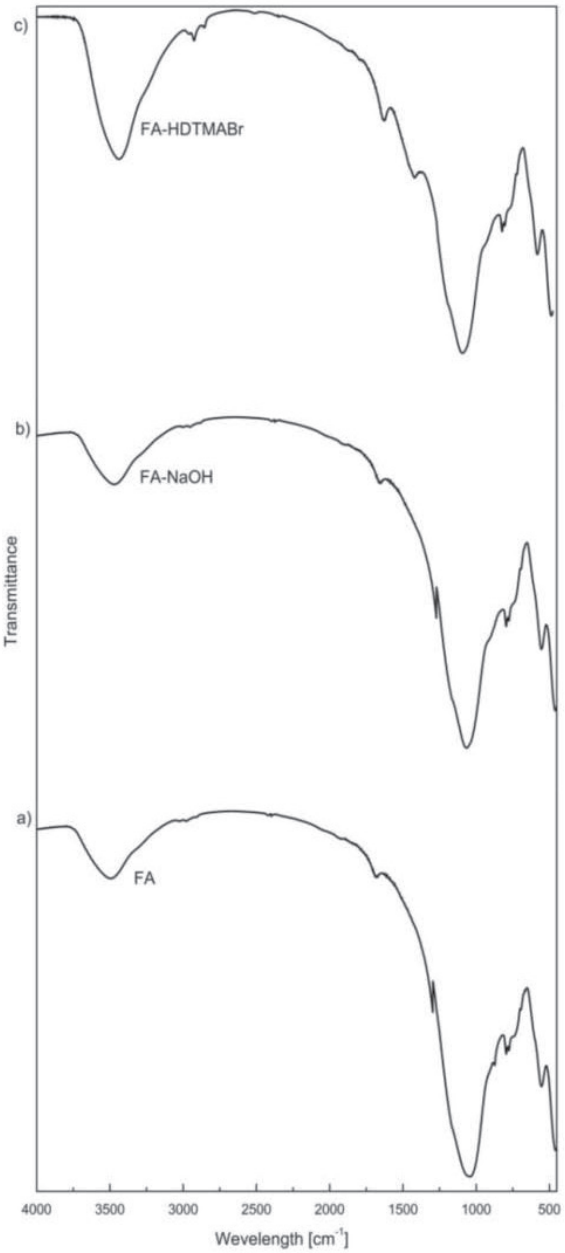

Fig. 1. 1) XRD patterns, 2) SEM images and 3) FT-IR spectra of a) coal fly ash (FA), b) FA treated with NaOH (FA-NaOH), and c) FA$\mathrm{NaOH}$ treated with surfactant (FA-HDTMABr)

studies also reported a similar observation [14]. After treatment with $\mathrm{NaOH}$, the ball-shaped particles of FA were partly transformed into smooth surface and agglomerations of various shapes with observations of crystal formation, e.g., plates and rods (Fig. 1-2b). The particle surface of $\mathrm{FA}-\mathrm{NaOH}$ showed the transformation of fly ash into a zeolite-like structure, as confirmed by the XRD data of this study (Fig. 1-1b) and was also observed by other studies [14]. The diffraction pattern of the FA-HDTMABr indicated that the modification process by HDTMABr did not crystallize and has been attached to the FA-NaOH surface (Fig. 1-1c). SEM observation of the FA (Fig. 1-2a) showed the presence of smaller particles and microspheres in the shape of smooth balls [15]. Modification of FA with $\mathrm{NaOH}$ affected the ball-shaped surfaces into agglomeration of micro-particles. This indicates change and increase in roughness of surface area (Fig. 1-2b), which is similar to Mor et al. [14]. Moreover, after treatment with a surfactant solution the surface morphology did not change (Fig. 1-2c).

Based on the spectrum obtained from the Fourier transform infrared analysis of the coal fly ash, we observed absorption broadband at $3400 \mathrm{~cm}^{-1}$, band at $1600 \mathrm{~cm}^{-1}$ and absorption broadband at about $1050 \mathrm{~cm}^{-1}$ (Fig. 1-3). The band at $3440 \mathrm{~cm}^{-1}$ originates from the $\mathrm{OH}$ group stretching vibrations [16]. This indicates the presence of both free and hydrogen-bonded -OH groups on the adsorbent surface.

The spectrum was in air atmosphere recorded, which is why clear-cut interpretation of this band was difficult because it could derive from -OH groups, chemically bonded with surface of FA, FA-NaOH and FA-HDTMABr (Fig. 1-3), and also from stretching vibrations $\mathrm{H}-\mathrm{O}-\mathrm{H}$ of water molecule adsorbed (peak at $3400 \mathrm{~cm}^{-1}$ ) on ash surface [16]. The increase of band intensity in the field of $3440 \mathrm{~cm}^{-1}$ in the spectrum of FA-HDTMABr can be observed (Fig. 1-3c). Coal fly ash modified by HDTMABr was more hydrophilic than that of the corresponding untreated sample. The presence of polar groups on the surface is likely to provide considerable cation exchange capacity to the adsorbents. The surface structure functional groups are by far the most important structures in influencing the surface characteristics and surface behaviour of FA-HDTMABr. The stretching of the $-\mathrm{OH}$ groups 
bound to methyl radicals presented a very weak signal $\sim 2900 \mathrm{~cm}^{-1}$ for FA and FA-NaOH (Figs 1-3a and 1-3b). Two consecutive, strong signals for FA-HDTMABr at 2920 and $2850 \mathrm{~cm}^{-1}$ were observed only on surfactantmodified coal fly ash (Fig. 1-3c), where additional bands derived from HDTMABr appear [11].

The bands could indicate that the $-\mathrm{OH}$ groups bound to aliphatic compounds correspond, respectively, to symmetric and asymmetric stretching vibrations of the methylene group $-\mathrm{CH}_{2}-$ [17]. The band at $1630 \mathrm{~cm}^{-1}$ related to bending vibrations of water molecules. The $1450 \mathrm{~cm}^{-1}$ band in FA, FA-NaOH and FA-HDTMABr may be attributed to aromatic $\mathrm{CH}$ and carboxylcarbonate structures. The highest intensity of bands in the spectrum of researched samples is in the field of $1050 \mathrm{~cm}^{-1}$ and can be described as asymmetric stretching vibrations of bridge bounds $v_{\text {as }}$ Si-O-Si and $v_{\text {as }}$ Si-O-Al, occurring in tetrahedral or aluminiumand silicon-oxygen bridges, typical for aluminosilicates framework structures [18]. The doublet of low intensity at ca. $800 \mathrm{~cm}^{-1}$ (integral at 798 and $780 \mathrm{~cm}^{-1}$ ) indicates the presence of quartz in the analysed samples. The symmetrical stretching of $v_{\mathrm{s}}$ Si-O-Al band (broadstrong) corresponds to the variation in frequency at $730 \mathrm{~cm}^{-1}$ and symmetrical stretching of $v_{\mathrm{s}}$ Si-O-Si band at $660 \mathrm{~cm}^{-1}$. Pseudolattice vibrations, originating from overtetrahedral structural units and the double ring of secondary building unit (SBU), can be observed to be present in the zeolite structure in the FA (rings made of siliconoxygen and aluminiumoxygen tetrahedra), corresponding to infrared frequency and equal to 550 $\mathrm{cm}^{-1}$. Moreover, the bans at about $550 \mathrm{~cm}^{-1}$ correspond to symmetric stretching vibrations of $v_{\mathrm{s}} \mathrm{Si}-\mathrm{O}-\mathrm{Si}$ bridge bonds and bending vibrations of $\delta \mathrm{O}-\mathrm{Si}-\mathrm{O}$ as complex bands [18]. Based on the FT-IR spectrum, it can be observed that there is the presence of pore openings corresponding to the band at $460 \mathrm{~cm}^{-1}$ in the FA, FA$\mathrm{NaOH}$ and FA-HDTMABr, which can be attributed to the dissolution of the minerals (viz., quartz and mullite) present in samples [14].

\section{Adsorption of Cd(II) Ions and Rhodamine B onto FA-HDTMABr}

\section{Influence of $p H$}

Distribution of the prevalent species of cadmium and $\mathrm{RB}$ in aqueous solution as a function of $\mathrm{pH}$ by using Minteq 3.0 software is presented in Fig. 2. At lower $\mathrm{pH}$ (2.0), the surface of the sorbent was more positive in character and there was competition between $\mathrm{H}^{+}$ions and $\mathrm{Cd}^{2+}$ ions for the active surface sites, and hence less adsorption was observed (Fig. 2a). As the $\mathrm{pH}$ increased from 2 to 3, the availability of the $\mathrm{OH}^{-}$group increased. When the solution $\mathrm{pH}$ is lower than 3 , the $\mathrm{RB}$ ion takes on a positive charge on one of the nitrogens while the carboxyl group is unionized. Also, below pH 3 RB molecules remain in monomeric form and dye molecule can easily enter into the pore structure of the adsorbent
[8]. The maximum removal (around 90\%) for RB was found at $\mathrm{pH}$ 3. With an increase in $\mathrm{pH}$ from 3 to 5 (at moderate $\mathrm{pH}$ ), the surface deprotonation of adsorbent occurs, leading to electrostatic attraction between the positively charged metal ions and the partially negatively charged adsorbent surface, which in turn increases the adsorption percentage of $\mathrm{Cd}(\mathrm{II})$ ions. At $\mathrm{pH}$ higher than 5 , the carboxyl group gets ionized and the zwitterions form of $\mathrm{RB}$ is formed [3], which in the water may increase the dimerization of RB (Fig. 2b), which makes the bigger molecules and thus unable to enter into the pore structure of sorbent. The removal of RB decreased to about $90 \%$ under highly acidic conditions $(\mathrm{pH} 3)$ and reached minimum (about 60\%) at $\mathrm{pH}$ 5. The process of precipitation $\left(\mathrm{Cd}(\mathrm{OH})_{2}\right)$ and adsorption $\left(\mathrm{CdOH}^{+}\right)$at $\mathrm{pH}$ 6-9 was observed. Moreover, at $\mathrm{pH}>9$ it was also the combined process of precipitation $\left(\mathrm{Cd}(\mathrm{OH})_{2}\right)$ and adsorption $\left(\mathrm{Cd}(\mathrm{OH})_{3}^{-}\right)$[19]. When the $\mathrm{pH}$ is higher than 7 the aggregation of $\mathrm{RB}$ decreases because excessive $\mathrm{OH}^{-}$competes with $\mathrm{COO}^{-}$in binding with $-\mathrm{N}^{+}$and the lactone form of RB is formed (Fig. 2b). However, when the $\mathrm{pH}$ of the solution was further increased $(\mathrm{pH} 8)$, the removal of RB increased to about $100 \%$. Therefore, both acidic and basic solutions are suitable for RB removal. RB is an aromatic amino acid with amphoteric characteristics due to the presence of both the amino group $\left(-\mathrm{NHR}_{2}\right)$ and the carboxyl group $(-\mathrm{COOH})$. The variation of $\mathrm{RB}$ removal with solution $\mathrm{pH}$ is similar to that reported previously [12], but is different from other adsorbents [20]. Thus, all further $\mathrm{Cd}(\mathrm{II})$ ions and RB studies were carried out at $\mathrm{pH}$ 9. All other experiments were conducted at $\mathrm{pH} 9$ unless otherwise mentioned. The $\mathrm{Cd}(\mathrm{II})$ ions and RB dye sorption is attributed to different mechanisms of the ion-exchange processes as well as to the adsorption. The mechanism of $\mathrm{Cd}(\mathrm{II})$ ions and RB dye sorption includes ion-exchange, surface adsorption process and also dissolution-reprecipitation in the case of $\mathrm{Cd}(\mathrm{II})$, as shown in Fig. 2c).

\section{Kinetic Studies}

The kinetic rate constants were calculated by using pseudo first-order (PFO) [21, 22], pseudo second-order (PSO) [22], Elovich kinetic models [23] and kinetic models, whereas the intra-particle diffusion model [23-25] and liquid film diffusion model [25] helped to determine the rate-controlling stage. Table 1 presents the values of these parameters. The kinetic sorption experimental data fit by using linear PFO and PSO equations were performed. The values of the reduced chi-square test and the coefficient of determination in the PSO model $\left(\mathrm{R}^{2}=0.996\right)$ were slightly lower for $\mathrm{Cd}(\mathrm{II})$ than those of the PFO model $\left(R^{2}<0.7\right)$, which is an indication that the PSO model is better than the PFO model. The PSO model is based on the assumption that the chemisorption occurs $[22,23]$. The kinetic sorption experimental data fit by using linear PSO equations are shown in Fig. 3a). The initial adsorption rate $u=k_{2} q_{e}^{2}$ and $q_{e}=q_{0}$, when $t \rightarrow 0$, can be calculated from the PSO 
a)

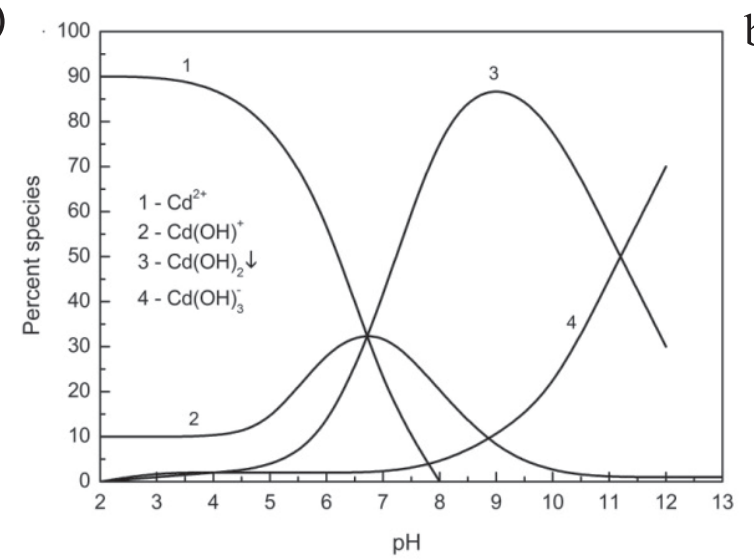

b)

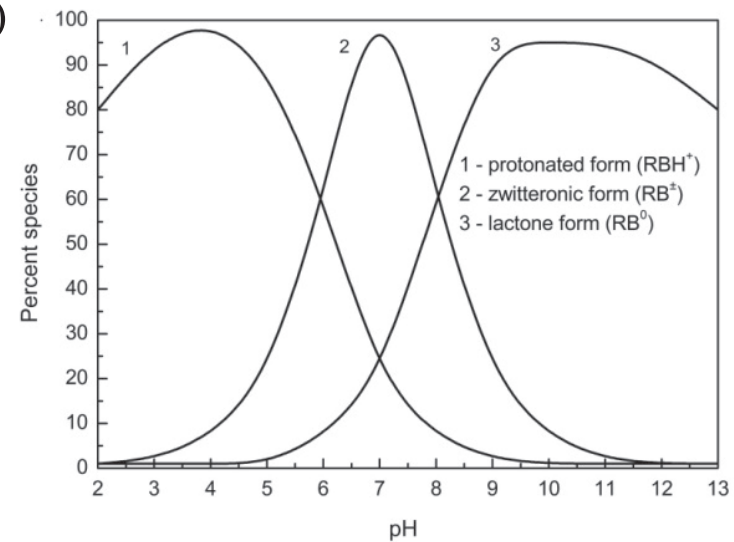

c)

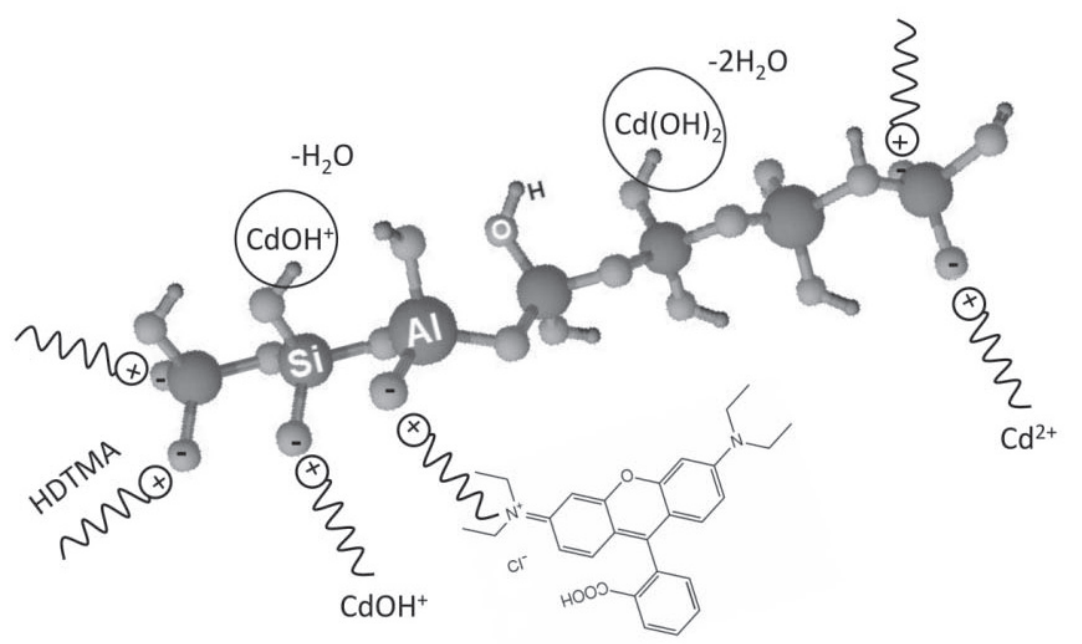

Fig. 2. Distribution of the prevalent species of a) $\mathrm{Cd}(\mathrm{II})$ ions, b) $\mathrm{RB}$ as a function of $\mathrm{pH}$, and c) $\mathrm{Cd}(\mathrm{II})$ ions and $\mathrm{RB}$ and mechanisms of sorption onto FA-HDTMABr.

Table 1. Kinetic model constants and correlation coefficients for the adsorption systems.

\begin{tabular}{|c|c|c|c|}
\hline Kinetic model & Parameter & $\mathrm{Cd}(\mathrm{II})$ & $\mathrm{RB}$ \\
\hline $\begin{array}{c}\text { Pseudo-first-order } \\
\mathrm{dq}_{\mathrm{t}} / \mathrm{dt}=\mathrm{k}_{1}\left(\mathrm{q}_{\mathrm{e}}-\mathrm{q}_{\mathrm{t}}\right) \\
\ln \left(\mathrm{q}_{\mathrm{e}}-\mathrm{q}_{\mathrm{t}}\right)=-\mathrm{k}_{\mathrm{l}} \mathrm{t}+\ln \mathrm{q}_{\mathrm{e}}\end{array}$ & $\begin{array}{c}\mathrm{k}_{1}\left[\min ^{-1}\right] \\
\mathrm{R}^{2}\end{array}$ & $\begin{array}{c}6.4 \cdot 10^{-3} \\
0.686\end{array}$ & $\begin{array}{c}3.3 \cdot 10^{-3} \\
0.738\end{array}$ \\
\hline $\begin{array}{c}\text { Pseudo-second-order } \\
\mathrm{dq}_{\mathrm{t}} / \mathrm{dt}=\mathrm{k}_{2}\left(\mathrm{q}_{\mathrm{e}}-\mathrm{q}_{\mathrm{t}}\right)^{2} \\
\mathrm{t} / \mathrm{q}_{\mathrm{t}}=1 / \mathrm{k}_{2} \mathrm{q}_{\mathrm{e}}^{2}+\mathrm{t} / \mathrm{q}_{\mathrm{e}}\end{array}$ & $\mathrm{k}_{2}\left[\mathrm{~g} \cdot \mathrm{mg}^{-1} \cdot \mathrm{min}^{-1}\right]$ & $\begin{array}{l}0.197 \\
0,996\end{array}$ & $\begin{array}{l}0.198 \\
0,964\end{array}$ \\
\hline $\begin{array}{c}\text { Elovich mass transfer } \\
\mathrm{dq}_{\mathrm{t}} / \mathrm{dt}=\alpha \exp \left(-\beta \mathrm{q}_{\mathrm{t}}\right) \\
\mathrm{q}_{\mathrm{t}}=1 / \beta \ln \mathrm{l}+1 / \beta \ln \alpha \beta\end{array}$ & $\begin{array}{c}\alpha\left[\mathrm{mg} \cdot \mathrm{g}^{-1} \cdot \mathrm{min}\right] \\
\beta\left[\mathrm{g} \cdot \mathrm{mg}^{-1}\right] \\
\mathrm{R}^{2}\end{array}$ & $\begin{array}{c}0.22 \\
0.72 \\
0.962 \\
\end{array}$ & $\begin{array}{c}1.44 \\
1.15 \\
0.734 \\
\end{array}$ \\
\hline $\begin{array}{l}\text { Liquid film diffusion } \\
\qquad \ln (1-\mathrm{F})=-\mathrm{k}_{\mathrm{fd}} \mathrm{t}\end{array}$ & $\begin{array}{c}\mathrm{k}_{\mathrm{fd}}\left[\mathrm{mg} \cdot \mathrm{g}^{-1} \cdot \mathrm{min}^{-1}\right] \\
\mathrm{R}^{2}\end{array}$ & $\begin{array}{c}1.1 \cdot 10^{-2} \\
0.667 \\
\end{array}$ & $\begin{array}{c}1.4 \cdot 10^{-2} \\
0.866 \\
\end{array}$ \\
\hline \multirow{2}{*}{$\begin{array}{l}\text { Intra-particle diffusion } \\
\qquad \mathrm{q}_{\mathrm{t}}=\mathrm{k}_{\mathrm{i}}^{\prime} \mathrm{t}^{1 / 2}+\mathrm{b}_{\mathrm{i}}\end{array}$} & $\begin{array}{c}\mathrm{k}_{1}{ }_{1}\left[\mathrm{mg} \cdot \mathrm{g}^{-1} \cdot \mathrm{min}^{-1 / 2}\right] \\
\mathrm{b}_{1}\left[\mathrm{mg} \cdot \mathrm{g}^{-1}\right] \\
\mathrm{R}^{2}\end{array}$ & $\begin{array}{c}0.639 \\
- \\
0.994 \\
\end{array}$ & $\begin{array}{c}0.645 \\
- \\
0.999 \\
\end{array}$ \\
\hline & $\begin{array}{c}\mathrm{k}_{2}\left[\mathrm{mg} \cdot \mathrm{g}^{-1} \cdot \mathrm{min}^{-1 / 2}\right] \\
\mathrm{b}_{2}\left[\mathrm{mg} \cdot \mathrm{g}^{-1}\right] \\
\mathrm{R}^{2}\end{array}$ & $\begin{array}{c}1.14 \cdot 10^{-7} \\
4.9 \\
1.000\end{array}$ & $\begin{array}{c}1.51 \cdot 10^{-5} \\
4.5 \\
0.997\end{array}$ \\
\hline $\begin{array}{l}\text { The initial adsorption rate } \\
\qquad \mathrm{u}=\mathrm{k}_{2} \mathrm{q}_{\mathrm{e}}^{2}\end{array}$ & $\mathrm{u}\left[\mathrm{mg} \cdot \mathrm{g}^{-1} \cdot \mathrm{min}^{-1}\right]$ & 4.90 & 4.95 \\
\hline $\begin{array}{l}\text { The half-adsorption time } \\
\qquad t_{1 / 2}=1 / \mathrm{k}_{2} \mathrm{q}_{\mathrm{e}}\end{array}$ & $\mathrm{t}_{1 / 2}[\mathrm{~min}]$ & 1.0 & 1.0 \\
\hline
\end{tabular}



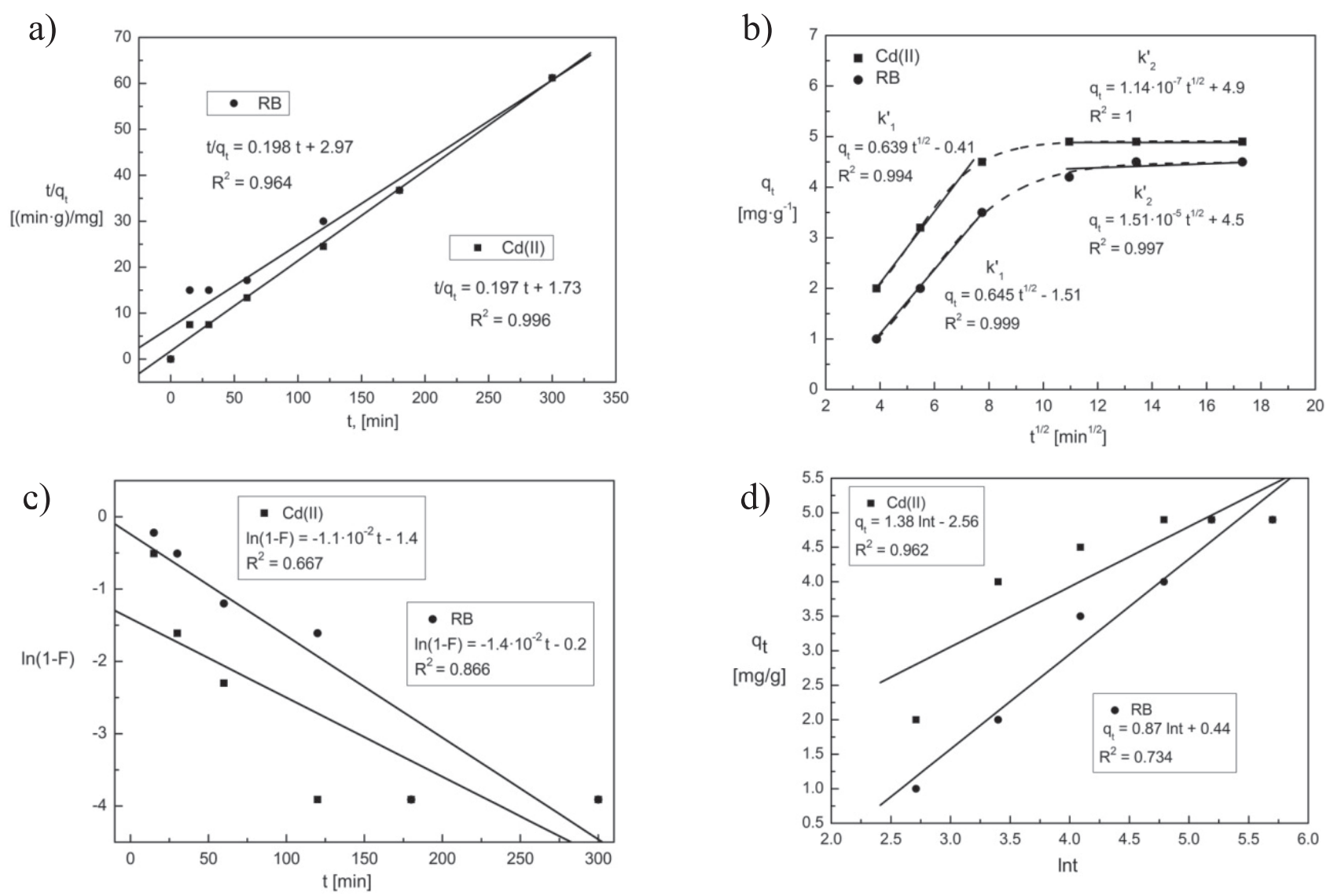

Fig. 3. Kinetics of $\mathrm{Cd}(\mathrm{II})$ and RB removal by FA-HDTMABr according to the model a) PSO, b) intra-particle diffusion, c) liquid film diffusion and d) Elovich mass transfer.

rate of equation. The initial adsorption rate of $\mathrm{Cd}(\mathrm{II})$ and $\mathrm{RB}$ were 4.90 and $4.95\left[\mathrm{mg} \cdot \mathrm{g}^{-1} \cdot \mathrm{min}^{-1}\right]$ respectively. The half time of adsorption of $\mathrm{Cd}$ (II) and $\mathrm{RB}$ were 1 min respectively for both sorbates. Multi linear plots $q_{t}=k_{i}^{\prime} t^{1 / 2}+b_{i}$ were indicated by two separate regions for adsorption of $\mathrm{Cd}(\mathrm{II})$ and $\mathrm{RB}$ [23]. Comparison of the micropore diffusion constant $k$, values for $\mathrm{Cd}(\mathrm{II})$ and $\mathrm{RB}$ were lower than those for the macropore diffusion constants $k^{\prime}$, of 0.639 and 0.645 , respectively for $\mathrm{Cd}(\mathrm{II})$ and $\mathrm{RB}$ (Fig. 3b). Moreover the rate of micropore diffusion is a slower step for determining rate step [26]. The boundary layer effect (second line from the plots of $q_{t}$ versus $t^{1 / 2}$ ) shows greater effect on the micropore diffusion stage (4.9 and 4.5), respectively for $\mathrm{Cd}(\mathrm{II})$ and $\mathrm{RB}$, than in the macropore stage, where it is close to zero. This indicates that the intraparticle diffusion is not only a rate-controlling step, but some other processes may control the rate of adsorption [1, 26].

Considering that the big dye molecules may diffuse very slowly across the liquid film over the adsorbent before interacting with the surface active sites, and that this may be the rate-determining step, the plots of $\ln (1-F)$ vs. $t$ are drawn to validate the liquid film diffusion model [26] where $F=q / q_{e}$ (the fractional attainment of equilibrium), and $\mathrm{k}_{\mathrm{fd}}$ is the diffusion rate coefficient. From the intercepts and slopes of
Fig. 3c), the film diffusion parameters were obtained and are shown in Table 1. The intercept values for both Cd(II) $\left(1.1 \cdot 10^{-2}\right)$ and RB $\left(1.4 \cdot 10^{-2}\right)$ are higher than zero, but are close to the origin showing the significance of liquid film diffusion in the rate determination of the adsorption process. The Elovich equation, which applies to heterogeneous surfaces [23, 24], was also applied in an effort to better describe the chemisorption process. A plot of $q_{t}$ versus lnt gives a linear trace with a slope of $1 / \beta$ and an intercept of $1 / \beta \ln \alpha \beta$. Linear plots with reasonable $R^{2}$ values indicate agreement with chemisorption processes contributing significantly to adsorption rates (Fig. 3d). However, experimental data again showed better agreement with the PSO kinetic model (Table 1).

\section{Equilibrium Studies}

The adsorption isotherm in the studied system was obtained by applying the Freundlich, Langmuir, generalized Langmiur-Freundlich, Redlich-Peterson, Jovanović, extended Jovanović, Tóth, Fumkin-FowlerGuggenheim, and Fowler-Guggenheim-JovanovićFreundlich, Temkin, Dubinin-Radushkevich, Halsey, Brunauer Emmett and Teller equals (Fig. 4).

The Freundlich isotherm is an empirical equation employed to describe heterogeneous systems [27]. 
The values of $1 / n$ or $n$ imply the type of isotherm and can be classified as irreversible $(1 / n=0$ or $n=1)$, the magnitude of $(0<1 / n<1$ or $1<n<10)$ indicates the favorability of the process of adsorption and unfavorable $(1 / n>1$ or $n>10)$ [4]. The obtained values of $1 / n$ showed the favourable nature of $\mathrm{Cd}(\mathrm{II})$ and $\mathrm{RB}$ adsorption and the heterogeneity of the adsorbent sites at studied temperature. From the data in Table 2, that values of $1 / n=0.56$ and $1 / n=0.59$ while $n=1.8$ and $n=1.7$, indicating that the sorption of $\mathrm{Cd}(\mathrm{II})$ and $\mathrm{RB}$ unto FA-HDTMABr is favourable and the $R^{2}$ values are 0.999 and 0.982 for $\mathrm{Cd}(\mathrm{II})$ and $\mathrm{RB}$, respectively. Furthermore, adsorption first occurs on the high-energy

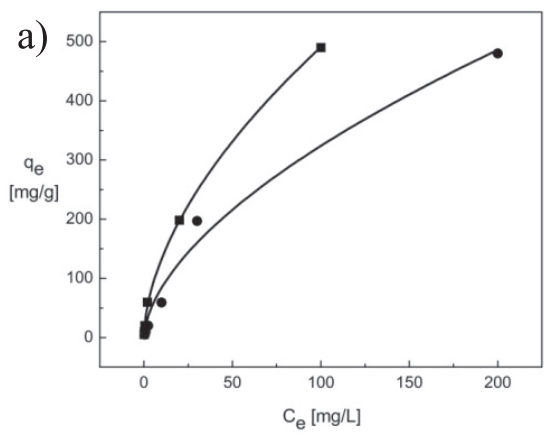

Freundlich isotherm

$\mathrm{q}_{\mathrm{e}}=\mathrm{K}_{\mathrm{F}} \cdot \mathrm{C}_{\mathrm{e}} \mathrm{e}^{1 / \mathrm{n}}$

- $\mathrm{Cd}(\mathrm{II})$

$\mathrm{R}^{2}=0.999$

$\chi^{2} /$ DoF $=0.38$

$\mathrm{K}_{\mathrm{F}}=35.9$

$\mathrm{n}=1.8$

$R^{2}=0.982$

$\chi^{2} /$ DoF $=6.4$

$\mathrm{K}_{\mathrm{F}}=21.8$

c)

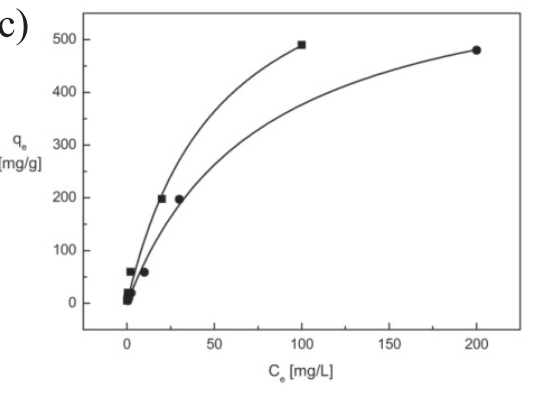

Generalized Langmuir and Freundlich isothe

$q_{e}=q_{x} \cdot\left(K_{L F} \cdot C_{e}\right)^{1 / n} /\left(1+\left(K_{L F} \cdot C_{e}\right)^{1 / n}\right)$

$\begin{array}{rl}-1 & C d(I I) \\ R^{2}=0.988\end{array}$

$x^{2} / D O F=4.4$
$\mathrm{q}_{\infty}=11.3$

$\mathrm{K}_{\mathrm{LF}}=1.9 \cdot 10^{-2}$

$n=1.5 \cdot 10^{-2}$

$n=1.5 \cdot 10^{2}$
$R^{2}=R B$
$R^{2}=0.996$

$\mathrm{x}^{2}=0.996$
$\mathrm{q}_{\mathrm{x}}=4.9$

$K_{L F}=1 \cdot 3 \cdot 10^{-2}$

$n=7 \cdot 3 \cdot 10^{-3}$
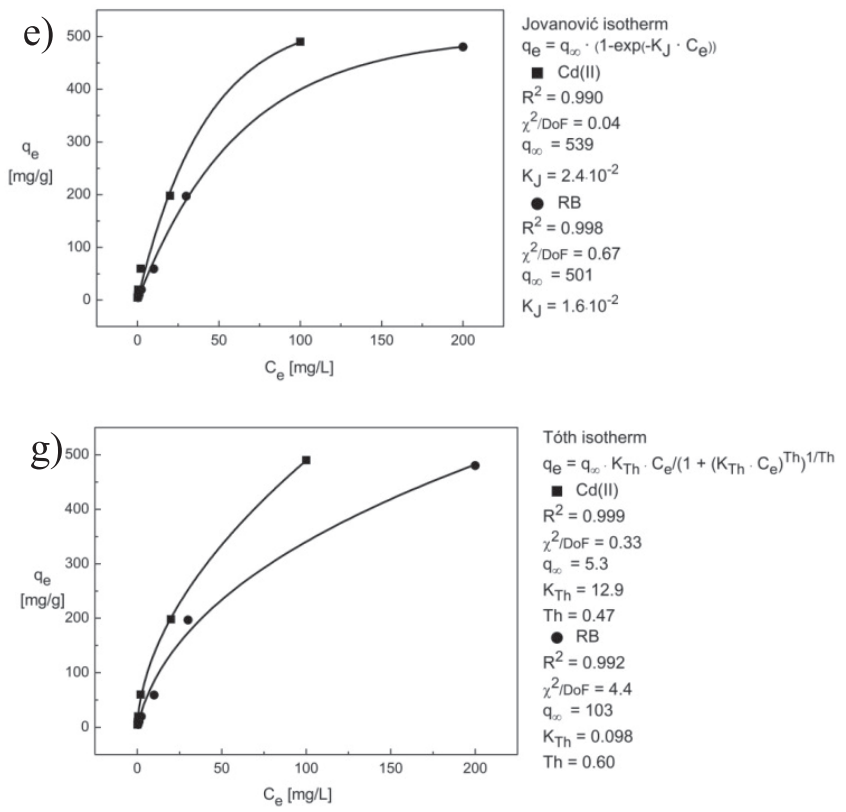

sites of sorbents, followed by the low-energy sites, which indicates that the adsorption isotherm follows L-type curves ( $\mathrm{n}>1)$ [28].

The obtained results indicate that the surface of FA-HDTMABr has a stronger affinity to $\mathrm{Cd}(\mathrm{II})$ ions than to dye cations. The selectivity sequence of metal and dye is generally explained on the basis of the properties of ion size, such as the smallest hydrated ionic radii (4.26 ) and RB cation weight. It is possible that the $\mathrm{Cd}(\mathrm{II})$ ions with fewer weakly bonded water molecules tend to move faster to potential adsorption sites on FA-HDTMABr, compared to the RB cations with higher ionic radii [19].
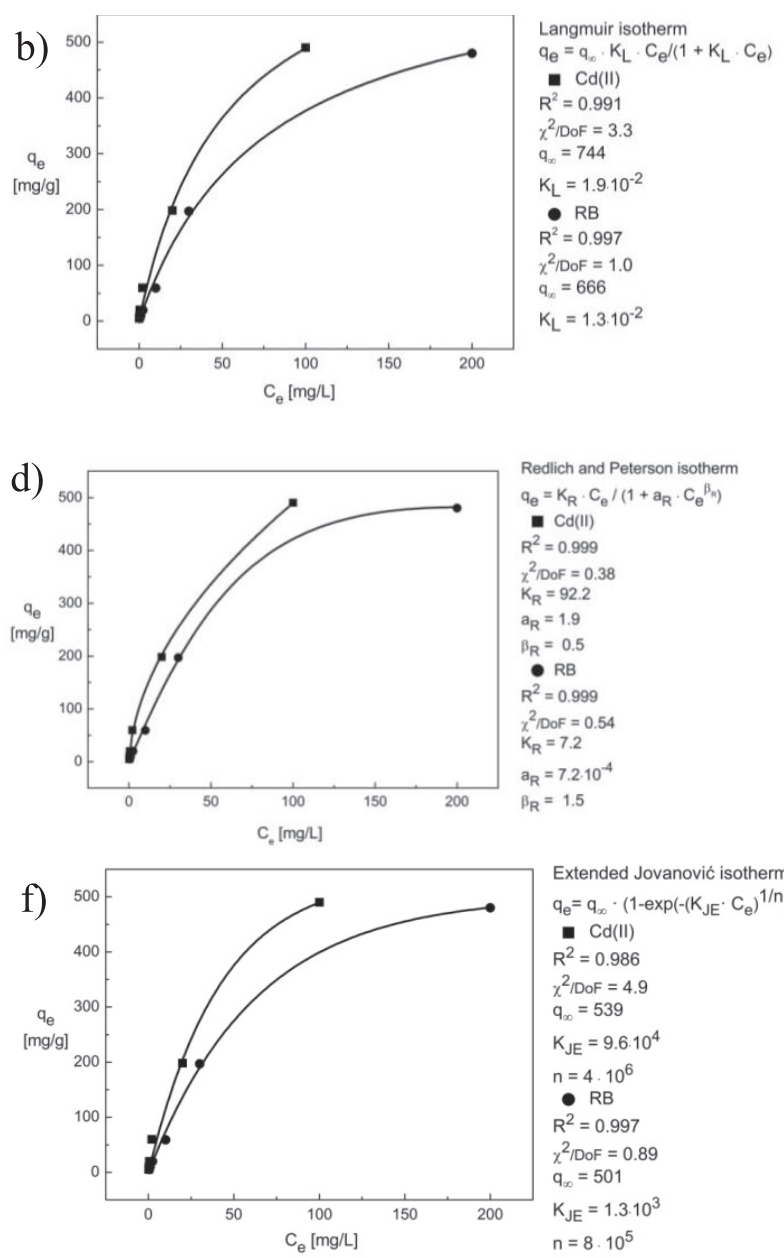

Extended Jovanović isotherm $\mathrm{q}_{\mathrm{e}}=\mathrm{q}_{\infty} \cdot\left(1-\exp \left(-\left(\mathrm{KJE}_{\mathrm{JE}} \cdot \mathrm{C}_{\mathrm{e}}\right)^{1 / \mathrm{n}}\right)\right.$ - $\mathrm{Cd}(\mathrm{II})$ $\mathrm{R}^{2}=0.986$ $\chi^{2} /$ DoF $=4.9$ $\mathrm{K}_{\mathrm{JE}}=9.6 \cdot 10^{4}$ $n=4 \cdot 10^{6}$ - RB $R^{2}=0.997$ $\chi^{2} /$ DoF $=0.89$ $\mathrm{K}_{\mathrm{JE}}=1 \cdot 3 \cdot 10^{3}$

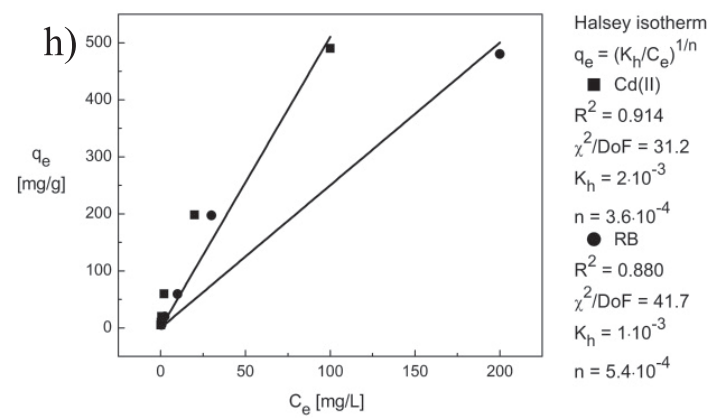

Fig. 4. Plot of isotherm models a) Freundlich, b) Langmuir, c) generalized Langmiur-Freundlich, d) Redlich-Peterson, e) Jovanović, f) extended Jovanović, g) Tóth, h) Halsey, i) Fumkin-Fowler-Guggenheim, j) Fowler-Guggenheim-Jovanović-Freundlich, k) Temkin, 1) Dubinin-Radushkevich, and m) Brunauer Emmett and Teller. 


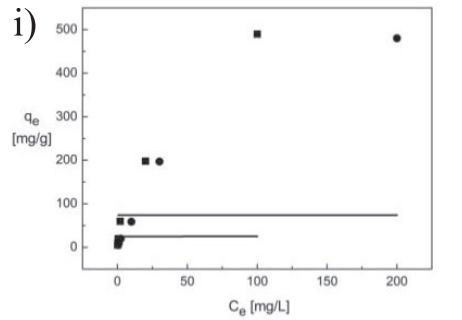

k)

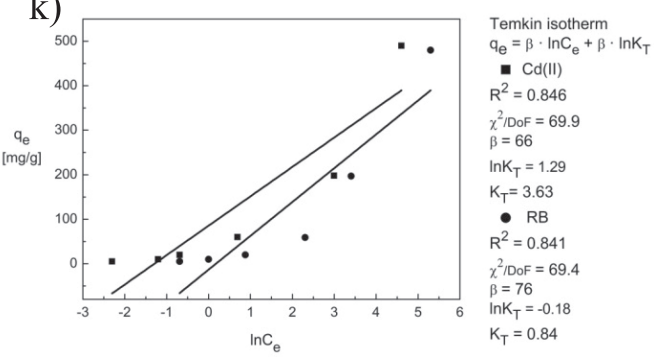

m)

$\mathrm{C} / \mathrm{C}_{0}$
(2)

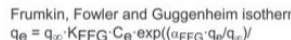

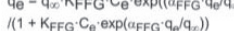

$-\mathrm{Cd}(I)$
$\mathrm{R}^{2}=0.013$

$x^{2} / D_{0} F=82$
$\mathrm{q}_{\mathrm{c}}=25$

$\mathrm{K}_{\mathrm{FFG}}=9.5$

$a_{F F G}=60.6$

$-\mathrm{RB}$
$\mathrm{R}^{2}=0.023$

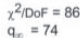

$\mathrm{K}_{\mathrm{FFG}}=12.1$
$\mathrm{~F}_{\mathrm{F}}=7.2$

emkin isotherm

$\mathrm{q}_{\mathrm{e}}=\beta \cdot \ln \mathrm{ne}_{\mathrm{e}}+\beta$

$R^{2}=0.846$

$=66$

$\mathrm{KK}_{\mathrm{T}}=1.29$

$\mathrm{K}_{\mathrm{T}}=3.63$

$R^{2}=0.84$

$\chi^{2}$ IDoF $=69.4$
$\beta=76$

$\mathrm{K}_{\mathrm{T}}=0.84$

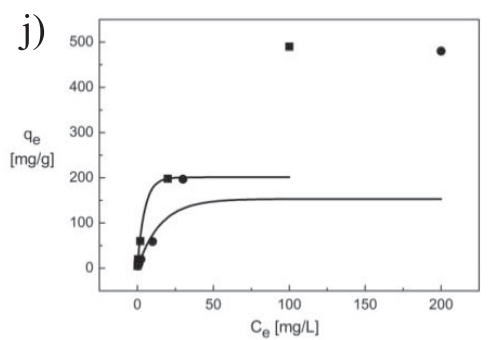

1)

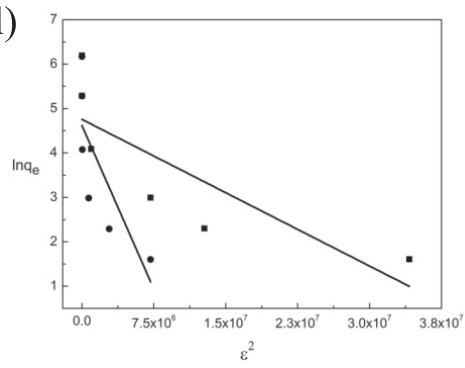

in and Radushkevich isother

$q_{e}=-K_{D R} \cdot \varepsilon^{2}+\ln q_{\infty}$

- $\mathrm{Cd}(\mathrm{II})$

${ }^{2} / \mathrm{DoF}=0.013$

$\mathrm{K}_{\mathrm{DR}}=1 \cdot 1 \cdot 10^{-7}$

$\operatorname{lnq}_{\mathrm{x}}=4.8$

- RB

$x^{2} / D=0.025$

${ }^{2} / \mathrm{DoF}=0.015$

$\mathrm{K}_{\mathrm{DR}}=4.9 \cdot 1$

$\begin{aligned} \operatorname{lnq}_{\infty x} & =4.6 \\ \mathrm{q}_{x} & =101.5\end{aligned}$

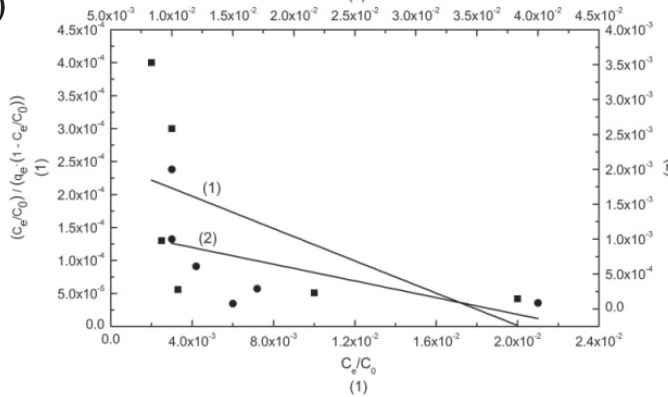

$\left(\mathrm{C}_{\mathrm{e}} / \mathrm{C}_{0}\right) /\left(\mathrm{q}_{\mathrm{e}} \cdot\left(1-\mathrm{C}_{\mathrm{e}} / \mathrm{C}_{0}\right)=\right.$

$=\left(\left(K_{B E T}-1\right) / K_{B E T} \cdot q_{\infty}\right) \cdot C_{e} / C_{0}+1 / K_{B E T} \cdot q_{\infty}$

\section{(1) $=\mathrm{Cd}(\mathrm{II})$}

$x^{2 / D o F}=1.9 \cdot 10^{-11}$

$\left(K_{\text {BET }}-1\right) / K_{\text {BET }} \cdot q_{\infty}=-1.2 \cdot 10^{-2}$

$1 / K_{\text {BET }} \cdot q_{\infty}=-2.5 \cdot 10^{-4}$

(2) $\bullet \mathrm{RB}$

$\mathrm{R}^{2}=0.312$

$x^{2} / \mathrm{DoF}=4.7 \cdot 10^{-9}$
$\left(K_{\text {BET }}-1\right) / K_{\text {BEE }} \cdot q_{\infty}=-3.6 \cdot 10^{-2}$

$1 / K_{\text {Ber }} \cdot q_{\infty}=1 \cdot 3 \cdot 10^{-3}$

Fig. 4. Continued.

Langmuir isotherm is often used to describe adsorption of solutes from liquid solutions and the model assumes monolayer adsorption onto a homogeneous surface with a finite number of identical sites [27, 28]. The adsorption parameters obtained from this model are given in Table 2. The maximum monolayer adsorption capacity $\mathrm{q}_{\infty}$ of the FA-HDTMABr was unaffected at $\mathrm{pH}$ 9 , but decreased at lower pHs, and were found to be 744 and $666 \mathrm{mg} \cdot \mathrm{g}^{-1}$ for $\mathrm{Cd}(\mathrm{II})$ and $\mathrm{RB}$ respectively.

The Generalized Langmuir and Freundlich (LF) isotherm [29] is a function that describes a specific relationship between the $q_{e}$ and $C_{e}$ in heterogeneous systems with three fitting coefficients: $q_{\infty}, K_{L F}$, and $n$. In contrast to the heterogeneous Freundlich isotherm, the Langmuir-Freundlich model has the advantage that it does not require an independent measure of the total number of binding sites $q_{\infty}$, which is very difficult to measure in heterogeneous sorbent. The total number of binding sites $q_{\infty}$ of the FA-HDTMABr were found to be 11.3 and $4.9 \mathrm{mg} \cdot \mathrm{g}^{-1}$ for $\mathrm{Cd}(\mathrm{II})$ and $\mathrm{RB}$ respectively. The obtained values of $n: 1.5 \cdot 10^{-2}$ and $1.3 \cdot 10^{-2}$ for $\mathrm{Cd}(\mathrm{II})$ and $\mathrm{RB}$, respectively, indicate that the FA-HDTMABr is a heterogeneous sorbent.

Redlich-Peterson (R-P) isotherm contains three parameters and is an improvement over the Langmuir and Freundlich isotherms. It can be applied in homogenous as well as heterogeneous systems [4, 6, 30]. Examination of the data showed that the R-P isotherm was appropriate descriptions of the data for Cd(II) sorption on the FA-HDTMABr in the studied concentration range $\left(\chi^{2} / \mathrm{DoF}=0.38 ; \mathrm{R}^{2}=0.999\right)$. The $\mathrm{R}-\mathrm{P}$ constant $\beta_{R}$ normally varies between 0 and 1 , indicating favorable adsorption. At high concentration $\left(\beta_{R} \rightarrow 0\right)$ the $\mathrm{R}-\mathrm{P}$ model approaches Freundlich isotherm and in accordance with low concentration $\left(\beta_{R} \rightarrow 1\right)$ it approaches Langmuir isotherm. As can be seen in Table 2, the value of $\beta_{R}$ was in this range $(0.5)$ only for $\mathrm{Cd}(\mathrm{II})$. The adsorption sequence is found to be in the order of increasing molecular weight and ionic radius, i.e., $\mathrm{Cd}(\mathrm{II})>\mathrm{RB}$.

The model of an adsorption surface considered by Jovanović [31] is essentially the same as that considered by Langmuir. Figs 4e) and 4f) show the comparison of the experimental data, Jovanović and Extended Jovanović (JE) model. The $\chi^{2} / \mathrm{DoF}$ values for the Jovanović model were a lower JE model. The JE isotherm takes into account the adsorption intensity $(1 / n)$; it also indicates the relative distribution of the energy and the heterogeneity of the adsorbate sites.

Dubinin-Radushkevich (D-R) isotherm [32] is applied to express the adsorption mechanism with a Gaussian energy distribution onto a heterogeneous 
Table 2. Values of isotherm adsorption parameters for removing Cd(II) and RB by FA-HDTMABr.

\begin{tabular}{|c|c|c|c|}
\hline Isotherm & Parameter & $\mathrm{Cd}(\mathrm{II})$ & $\mathrm{RB}$ \\
\hline \multirow{4}{*}{$\begin{array}{c}\text { Freundlich } \\
\mathrm{q}_{\mathrm{e}}=\mathrm{K}_{\mathrm{F}} \cdot\left(\mathrm{C}_{\mathrm{e}}\right)^{\frac{1}{\mathrm{n}}}\end{array}$} & $\mathrm{K}_{\mathrm{F}} \mathrm{mg}^{1-1 / \mathrm{n}} \cdot \mathrm{L}^{1 / \mathrm{n}} \cdot \mathrm{g}^{-1}$ & 35.9 & 21.8 \\
\hline & $\mathrm{n}$ & 1.8 & 1.7 \\
\hline & $\mathrm{R}^{2}$ & 0.999 & 0.982 \\
\hline & $\chi^{2} / \mathrm{DoF}$ & 0.38 & 6.4 \\
\hline \multirow{4}{*}{$\begin{array}{l}\text { Langmuir } \\
\mathrm{q}_{\infty} \frac{\mathrm{K}_{\mathrm{L}} \cdot \mathrm{C}_{\mathrm{e}}}{1+\mathrm{K}_{\mathrm{L}} \cdot \mathrm{C}_{\mathrm{e}}}\end{array}$} & $\mathrm{K}_{\mathrm{L}} \mathrm{L} \cdot \mathrm{mg}^{-1}$ & $1.9 \cdot 10^{-2}$ & $1.3 \cdot 10^{-2}$ \\
\hline & $\mathrm{q}_{\infty} \mathrm{mg} \cdot \mathrm{g}^{-1}$ & 744 & 666 \\
\hline & $\mathrm{R}^{2}$ & 0.991 & 0.997 \\
\hline & $\chi^{2} / \mathrm{DoF}$ & 3.3 & 1.0 \\
\hline \multirow[t]{5}{*}{ Generalized Langmuir and Freundlich } & $\mathrm{K}_{\mathrm{LF}} \mathrm{L} \cdot \mathrm{mg}^{-1}$ & $1.9 \cdot 10^{-2}$ & $1.3 \cdot 10^{-2}$ \\
\hline & $\mathrm{q}_{\infty} \mathrm{mg} \cdot \mathrm{g}^{-1}$ & 11.3 & 4.9 \\
\hline & $\mathrm{n}$ & $1.5 \cdot 10^{-2}$ & $7.3 \cdot 10^{-3}$ \\
\hline & $\mathrm{R}^{2}$ & 0.988 & 0.996 \\
\hline & $\chi^{2} / \mathrm{DoF}$ & 4.4 & 1.4 \\
\hline \multirow{5}{*}{$\begin{array}{l}\text { Redlich and Peterson } \\
\mathrm{q}_{\mathrm{e}}=\frac{\mathrm{K}_{\mathrm{R}} \cdot \mathrm{C}_{\mathrm{e}}}{1+\mathrm{a}_{\mathrm{R}} \cdot \mathrm{C}_{\mathrm{e}}^{\beta_{R}}}\end{array}$} & $\mathrm{~K}_{\mathrm{R}} \mathrm{L} \cdot \mathrm{g}^{-1}$ & 92.2 & 7.2 \\
\hline & $a_{R}\left(L \cdot \mathrm{mg}^{-1}\right)^{\beta R}$ & 1.9 & $7.2 \cdot 10^{-4}$ \\
\hline & $\beta_{\mathrm{R}}$ & 0.5 & 1.5 \\
\hline & $\mathrm{R}^{2}$ & 0.999 & 0.999 \\
\hline & $\chi^{2} / \mathrm{DoF}$ & 0.38 & 0.54 \\
\hline \multirow{4}{*}{$\begin{array}{c}\text { Jovanović } \\
\mathrm{q}_{\mathrm{e}}=\mathrm{q}_{\infty}\left(1-\exp \left(-\mathrm{K}_{\mathrm{J}} \cdot \mathrm{C}_{\mathrm{e}}\right)\right)\end{array}$} & $\mathrm{K}_{\mathrm{J}} \mathrm{L} \cdot \mathrm{mg}^{-1}$ & $2.4 \cdot 10^{-2}$ & $1.6 \cdot 10^{-2}$ \\
\hline & $\mathrm{q}_{\infty} \mathrm{mg} \cdot \mathrm{g}^{-1}$ & 539 & 501 \\
\hline & $\mathrm{R}^{2}$ & 0.990 & 0.998 \\
\hline & $\chi^{2} / \mathrm{DoF}$ & 0.04 & 0.67 \\
\hline \multirow{5}{*}{$\begin{array}{c}\text { Extended Jovanović } \\
\mathrm{q}_{\mathrm{e}}=\mathrm{q}_{\infty}\left(1-\exp \left(-\left(\mathrm{K}_{\mathrm{JE}} \cdot \mathrm{C}_{\mathrm{e}}\right)^{\frac{1}{\mathrm{n}}}\right)\right.\end{array}$} & $\mathrm{K}_{\mathrm{JE}} \mathrm{L} \cdot \mathrm{mg}^{-1}$ & $9.6 \cdot 10^{4}$ & $1.3 \cdot 10^{3}$ \\
\hline & $\mathrm{q}_{\infty} \mathrm{mg} \cdot \mathrm{g}^{-1}$ & 539 & 501 \\
\hline & $\mathrm{n}$ & $4.0 \cdot 10^{6}$ & $8.0 \cdot 10^{5}$ \\
\hline & $\mathrm{R}^{2}$ & 0.986 & 0.997 \\
\hline & $\chi^{2} / \mathrm{DoF}$ & 4.9 & 0.89 \\
\hline \multirow{5}{*}{$\mathrm{q}_{\mathrm{e}}=\mathrm{q}_{\infty} \frac{\mathrm{K}_{\mathrm{Th}} \cdot \mathrm{C}_{\mathrm{e}}}{\left(1+\left(\mathrm{K}_{\mathrm{Th}} \cdot \mathrm{C}_{\mathrm{e}}\right)^{\mathrm{Th}}\right)^{\frac{1}{\mathrm{Th}}}}$} & $\mathrm{K}_{\mathrm{Th}}\left(\mathrm{L} \cdot \mathrm{mg}^{-1}\right)^{\mathrm{Th}}$ & 12.9 & 0.098 \\
\hline & $\mathrm{q}_{\infty} \mathrm{mg} \cdot \mathrm{g}^{-1}$ & 5.3 & 103 \\
\hline & Th & 0.47 & 0.60 \\
\hline & $\mathrm{R}^{2}$ & 0.999 & 0.992 \\
\hline & $\chi^{2} / \mathrm{DoF}$ & 0.33 & 4.4 \\
\hline \multirow{4}{*}{$\begin{array}{c}\text { Halsey } \\
\mathrm{q}_{\mathrm{e}}=\left(\frac{\mathrm{K}_{\mathrm{h}}}{\mathrm{C}_{\mathrm{e}}}\right)^{\frac{1}{\mathrm{n}}}\end{array}$} & $\mathrm{K}_{\mathrm{h}} \mathrm{mg}^{\mathrm{n}-1} \cdot \mathrm{g}^{-\mathrm{n}} \cdot \mathrm{L}$ & $2.0 \cdot 10^{-3}$ & $1.0 \cdot 10^{-3}$ \\
\hline & $\mathrm{n}$ & $3.6 \cdot 10^{-4}$ & $5.4 \cdot 10^{-4}$ \\
\hline & $\mathrm{R}^{2}$ & 0.914 & 0.880 \\
\hline & $\chi^{2} / \mathrm{DoF}$ & 31.2 & 41.7 \\
\hline
\end{tabular}


Table 2. Values of isotherm adsorption parameters for removing Cd(II) and RB by FA-HDTMABr.

\begin{tabular}{|c|c|c|c|}
\hline \multirow{5}{*}{$\begin{array}{l}\text { Fumkin, Fowler and Guggenheim } \\
\mathrm{q}_{\mathrm{e}}=\mathrm{q}_{\infty} \frac{\mathrm{K}_{\mathrm{FFG}} \cdot \mathrm{C}_{\mathrm{e}} \cdot \exp \left(\frac{\alpha_{\mathrm{FFG}} \mathrm{q}_{\mathrm{e}}}{\mathrm{q}_{\infty}}\right)}{1+\mathrm{K}_{\mathrm{FFG}} \cdot \mathrm{C}_{\mathrm{e}} \cdot \exp \left(\frac{\alpha_{\mathrm{FFG}} \mathrm{q}_{\mathrm{e}}}{\mathrm{q}_{\infty}}\right)}\end{array}$} & $\mathrm{K}_{\mathrm{FFG}} \mathrm{L} \cdot \mathrm{g}^{-1}$ & 9.5 & 12.1 \\
\hline & $\mathrm{q}_{\infty} \mathrm{mg} \cdot \mathrm{g}^{-1}$ & 25 & 74 \\
\hline & $\alpha_{\mathrm{FFG}}$ & 60.6 & 85.3 \\
\hline & $\mathrm{R}^{2}$ & 0.013 & 0.023 \\
\hline & $\chi^{2} / \mathrm{DoF}$ & 82 & 86 \\
\hline Fowler, Guggenheim, Jovanović and Freundlich & $\mathrm{K}_{\mathrm{FGJF}} \mathrm{L} \cdot \mathrm{g}^{-1}$ & 87.6 & 58.7 \\
\hline & $\mathrm{q}_{\infty} \mathrm{mg} \cdot \mathrm{g}^{-1}$ & 201 & 153 \\
\hline$\left.\left({ }_{K} \quad\left(\alpha_{\mathrm{FGJF}} \mathrm{q}_{\mathrm{e}}\right)\right)^{\frac{1}{\mathrm{n}}}\right)$ & $\alpha_{\mathrm{FGJF}}$ & 856 & 643 \\
\hline $\mathrm{q}_{\mathrm{e}}=\mathrm{q}_{\infty} \cdot\left(1-\exp \left(-\left(\mathrm{K}_{\mathrm{FGJF}} \cdot \mathrm{C}_{\mathrm{e}} \cdot \exp \left(\frac{\mathrm{q}_{\infty}}{\mathrm{c}}\right)\right)\right)\right.$ & $\mathrm{n}$ & 962.1 & 893.6 \\
\hline & $\mathrm{R}^{2}$ & 0.012 & 0.022 \\
\hline & $\chi^{2} / \mathrm{DoF}$ & $1.2 \cdot 10^{3}$ & $7.8 \cdot 10^{2}$ \\
\hline & $\mathrm{K}_{\mathrm{T}} \mathrm{L} \cdot \mathrm{g}^{-1}$ & 3.63 & 0.84 \\
\hline $\mathrm{q}_{\mathrm{e}}=\beta_{T} \ln \mathrm{K}_{\mathrm{T}}+\beta_{T} \ln \mathrm{C}_{\mathrm{e}}$ & $\beta_{\mathrm{T}} \mathrm{J} \cdot \mathrm{mol}^{-1}$ & 66 & 76 \\
\hline$\beta_{T}=\frac{\mathrm{RT}}{\mathrm{b}}$ & $\mathrm{b}$ & 38 & 33 \\
\hline & $\mathrm{R}^{2}$ & 0.846 & 0.841 \\
\hline & $\chi^{2} / \mathrm{DoF}$ & 69.9 & 69.4 \\
\hline Dubinin and Radushkevich & $\mathrm{K}_{\mathrm{DR}} \mathrm{mol}^{2} \cdot \mathrm{kJ}^{-2}$ & $1.1 \cdot 10^{-7}$ & $4.9 \cdot 10^{-7}$ \\
\hline $\operatorname{lnq} q_{e}=-K_{D R} \cdot \varepsilon^{2}+\ln q_{\infty}$ & $\mathrm{q}_{\infty} \mathrm{mg} \cdot \mathrm{g}^{-1}$ & 121.5 & 101.5 \\
\hline$E=\frac{1}{-1}$ & $\mathrm{E} \quad \mathrm{kJ} \cdot \mathrm{mol}^{-1}$ & 2.1 & 1.0 \\
\hline$\left(2 \mathrm{~K}_{\mathrm{DR}}\right)^{\frac{1}{2}}$ & $\mathrm{R}^{2}$ & 0.676 & 0.625 \\
\hline$\varepsilon=\mathrm{RT} \ln \left(1+\frac{1}{\mathrm{C}_{\mathrm{e}}}\right)$ & $\chi^{2} / \mathrm{DoF}$ & 0.013 & 0.015 \\
\hline Brunauer, Emmett and Teller & $\mathrm{K}_{\mathrm{BET}} \mathrm{L} \cdot \mathrm{g}^{-1}$ & - & - \\
\hline$\frac{\mathrm{C}_{\mathrm{e}}}{\mathrm{C}} \quad \mathrm{K}_{\mathrm{D}}-1$ & $\mathrm{q}_{\infty} \mathrm{mg} \cdot \mathrm{g}^{-1}$ & - & - \\
\hline$\frac{\mathrm{C}_{0}}{\left(1-\underline{\mathrm{C}_{\mathrm{e}}}\right)}=\mathrm{q}_{\infty} \frac{\mathrm{K}_{\text {BET }}-1}{\mathrm{~K}_{\text {BET }} \cdot \mathrm{q}_{\infty}} \cdot \frac{\mathrm{C}_{\mathrm{e}}}{\mathrm{C}_{0}}+\frac{1}{\mathrm{~K}_{\text {BET }} \cdot \mathrm{q}_{\infty}}$ & $\mathrm{R}^{2}$ & 0.331 & 0.312 \\
\hline $\mathrm{q}_{\mathrm{e}}\left(1-\overline{\mathrm{C}_{0}}\right)$ & $\chi^{2} / \mathrm{DoF}$ & $1.9 \cdot 10^{-11}$ & $4.7 \cdot 10^{-9}$ \\
\hline
\end{tabular}

surface [33]. The D-R model has often fitted high concentrations of data well, but has poor properties at low concentration of metal ions. The calculated mean free energy, E per molecule of adsorbate is usually applied to distinguish the physical and chemical adsorption of metal ions. The D-R isotherm at different temperatures is plotted as a function of logarithm of the amount adsorbed vs. the square of potential energy because this model is dependent on temperature [32]. The experimental data for sorption of $\mathrm{Cd}(\mathrm{II})$ and $\mathrm{RB}$ do not correlate as well with the D-R model and this is confirmed by the error parameter shown in Table 2 . The value of free energy was between 1 and $8 \mathrm{~kJ} \cdot \mathrm{mol}^{-1}$ on the basis of the linear plot of the D-R model, E was determined to $2.1 \mathrm{~kJ} \cdot \mathrm{mol}^{-1}$ and $1.0 \mathrm{~kJ} \cdot \mathrm{mol}^{-1}$ for $\mathrm{Cd}(\mathrm{II})$ and $\mathrm{RB}$, respectively, indicating that physisorption may play a significant role in the adsorption process $[27,34]$. The typical bonding energy range for the ionexchange mechanism is in the range of $8-16 \mathrm{~kJ} \cdot \mathrm{mol}^{-1}$
[34]. The obtained maximum content of sorbate in FAHDTMABr at the sorption equilibrium was $121.5 \mathrm{mg} \cdot \mathrm{g}^{-1}$ $\left(\mathrm{R}^{2}=0.676\right)$ and $101.5 \mathrm{mg} \cdot \mathrm{g}^{-1}\left(\mathrm{R}^{2}=0.625\right)$ for $\mathrm{Cd}(\mathrm{II})$ and $\mathrm{RB}$, respectively.

Temkin isotherm [32, 35] contains a factor taking into account the adsorbent-adsorbate interactions. The model describes that adsorption heat as a function of temperature of all molecules in the layer would decrease linearly rather than logarithmically [32]. The Temkin isotherm fits the gas phase equilibrium well, but this model is not appropriate to be the expressed adsorption process in the liquid systems [35]. From the linear plot of the Temkin model (Fig. 4k), free energy was determined as $66 \mathrm{~J} \cdot \mathrm{mol}^{-1}$ and $76 \mathrm{~J} \cdot \mathrm{mol}^{-1}$ for $\mathrm{Cd}(\mathrm{II})$ and $\mathrm{RB}$, respectively, indicating a physisorption process and $\mathrm{R}^{2}=0.846$ and $\mathrm{R}^{2}=0.841$ higher than that of the $\mathrm{D}-\mathrm{R}$ isotherm.

Frumkin-Fowler-Guggenheim (FFG) and FowlerGuggenheim-Jovanović-Freundlich (FGJF) equals have 
been defined and applied to adsorption, where $\alpha_{F F G}$ and $\alpha_{F G J F}$ indicate the number of interacting molecules (interaction energy) [36]. For the studied system (Cd(II) and RB), when the values of surface coverage are calculated using the Langmuir or L-F maximum adsorption capacities, the FFG and FGJF models are unable to simulate the experimental results of the adsorption isotherms. The isotherms using the equation of FFG and FGJF are shown in Figs. 4(i-j).

The multilayer adsorption isotherms are suitable for proving the heteroporous nature of adsorbent. One example is the Tóth isotherm model, which has been applied for the modelling of several multilayer and heterogeneous adsorption systems [30, 37]. The parameter $T h$ characterizes the heterogeneity of the adsorption system and when $T h=1$, this equation reduces the Langmuir isotherm equation. Its model assumes an asymmetrical quasi-Gaussian energy distribution, with most sites having sorption energy lower than the maximum of peak or mean value [34]. The application of this isotherm is best suited to multilayer adsorption similar to Halsey [38] and Brunauer-Emmett-Teller (BET) [32]. The BET model is a theoretical equation, most widely applied in the gas-solid equilibrium systems, but its extended model can also be related to liquid-solid interface. Researched equations are based on a kinetic principle assuming that the adsorption sites increase exponentially with adsorption, which implies multilayer adsorption [32]. The values of $\chi^{2} /$ DoF (Table 2 ) for the Halsey, BET and Tóth models are considerably higher than other models, suggesting that the multilayer model could not describe the experimental data satisfactorily for the adsorption of $\mathrm{Cd}(\mathrm{II})$ and $\mathrm{RB}$ on FA-HDTMABr.

A comparison of the obtained $\chi^{2} / \mathrm{DoF}$ values indicates that the Langmuir, Jovanovic and R-P models best fit the $\mathrm{Cd}(\mathrm{II})$ and $\mathrm{RB}$ adsorption on the FA-HDTMABr. Figs 4(b, d, e) and Table 2 confirm the good fit of researched isotherms with the experimental data for removal of $\mathrm{Cd}(\mathrm{II})$ and $\mathrm{RB}$ from the aqueous solution. These models show a high degree of correlation with low reduced chi-square values. On the basis of error values obtained for both sorbates of the considered isotherms, the fitting degree follows the following sequence: Langmuir $>$ Jovanović> R-P $>$ Tóth $>$ Freundlich $>$ L-F $>$ JE $>$ Halsey $>$ Temkin $>$ D-R $>$ FFG $>$ FGJF $>$ BET. The D-R approach was applied to distinguish the physical and chemical adsorption of $\mathrm{Cd}(\mathrm{II})$ and $\mathrm{RB}$ on the basis of its mean free energy per mol of FA-HDTMABr. The energy value obtained according to this model $\left(2.1 \mathrm{~kJ} \cdot \mathrm{mol}^{-1}\right.$ and $1.0 \mathrm{~kJ} \cdot \mathrm{mol}^{-1}$ for $\mathrm{Cd}(\mathrm{II})$ and $\mathrm{RB}$ ) was less than $8.0 \mathrm{~kJ} \cdot \mathrm{mol}^{-1}$. This result indicates that the adsorption of $\mathrm{Cd}(\mathrm{II})$ and $\mathrm{RB}$ onto FAHDTMABr follows the physisorption process.

As can be seen from the data calculated in Table 2, the value of the maximum monolayer adsorption capacity $\mathrm{q}_{\infty}$ on the FA-HDTMABr for both sorbates from Langmuir model was very close to the experimental value and was found to be 744 and $666 \mathrm{mg} \cdot \mathrm{g}^{-1}$ for $\mathrm{Cd}(\mathrm{II})$ and $\mathrm{RB}$ respectively. The maximum monolayer adsorption capacity values of various low-cost adsorbents were reported in the literature. A comparison between these values and obtained results for FA-HDTMABr show reasonable capacity and can be used as a good and inexpensive adsorbent for removal of $\mathrm{Cd}(\mathrm{II})$ and $\mathrm{RB}$ from aqueous solution.

\section{Conclusions}

A laboratory test demonstrated that the modified FA-NaOH by HDTMABr worked well for the removal of $\mathrm{Cd}(\mathrm{II})$ and $\mathrm{RB}$ from polluted waters. The obtained results show that FA-HDTMABr is a more effective adsorbent than FA. The effects of operating parameters such as $\mathrm{pH}$, contact time, and initial metal and dye dose on $\mathrm{Cd}(\mathrm{II})$ and RB sorption capacity of FA-HDTMABr were studied. The maximum monolayer adsorption capacity of the FA-HDTMABr was unaffected at $333 \mathrm{~K}, 1$ hour and $\mathrm{pH}$ 9, but decreased at lower $\mathrm{pH}$. $\mathrm{RB}$ is an aromatic amino acid with amphoteric characteristics due to the presence of both the amino group (-NHR2) and the carboxyl group $(-\mathrm{COOH})$. Moreover at $\mathrm{pH}>9$ it was also a combined process of precipitation $(\mathrm{Cd}(\mathrm{OH}) 2)$ and adsorption $\left(\mathrm{Cd}(\mathrm{OH}) 3^{-}\right)$. Thus, all further $\mathrm{Cd}(\mathrm{II})$ ions and $\mathrm{RB}$ studies were carried out at $\mathrm{pH} 9$. The $\mathrm{Cd}(\mathrm{II})$ ions and $\mathrm{RB}$ dye sorption is attributed to different mechanisms of the ion-exchange processes as well as to the adsorption. The mechanism of $\mathrm{Cd}(\mathrm{II})$ ions and RB dye sorption includes ion-exchange, surface adsorption process and also dissolution-reprecipitation in the case of $\mathrm{Cd}(\mathrm{II})$. It can be concluded that the FA-HDTMABr can be used for removal of $\mathrm{Cd}(\mathrm{II})$ and RB from solutions with maximum uptake of 744 and $666 \mathrm{mg} \bullet \mathrm{g}-1$ respectively. Kinetic studies demonstrated that the mechanism for adsorption of metal ions followed the PSO rate model, providing the best fit for the experimental data $(\mathrm{R} 2=0.996)$, but showing a very poor fit for the PFO model $(\mathrm{R} 2<0.7)$. The intra-particle diffusion model suggested that the initial adsorption rate was controlled by film diffusion, which was followed by pore diffusion or the external mass transfer effects. A comparison of the obtained $\chi 2 /$ DoF values indicated that the adsorption equilibrium was described well by the Langmuir, Jovanovic and R-P isotherm. The competitive adsorption experiment indicated that FA-HDTMABr had a stronger affinity to $\mathrm{Cd}$ (II) than to $\mathrm{RB}$, which is related to their ionic radius. Improving the morphology properties and adsorption capacity of $94 \%$ indicates the possibility of the FA-HDTMABr application as effective and economically adsorbent for removing $\mathrm{Cd}(\mathrm{II})$ and $\mathrm{RB}$ from water and wastewaters. 


\section{Abbreviations}

Latin letters

$a_{R}-$ Redlich and Peterson constant, $\left(\mathrm{L} \cdot \mathrm{mg}^{-1}\right)^{\beta}{ }_{R}$

$b_{i}$ - film thickness, $\mathrm{mg} \cdot \mathrm{g}^{-1}$

$C_{0}$ - initial concentration of sorbate in the solution, $\mathrm{mg} \cdot \mathrm{L}^{-1}$

$C_{e}$ - unadsorbed concentration of the component in an aqueous solution at the sorption equilibrium, $\mathrm{mg} \cdot \mathrm{L}^{-1}$

$C E C$ - cation exchange capacity, $\mathrm{mmol} \cdot \mathrm{g}^{-1}$

$C_{t}$ - concentration of sorbate in the solution after sorption, $\mathrm{mg} \cdot \mathrm{L}^{-1}$

$D o F$ - degrees of freedom

$E$ - free energy, $\mathrm{kJ} \cdot \mathrm{mol}^{-1}$

$F$ - fractional attainment of equilibrium

$F A$ - fly ash

FAAS - Flame atomic absorption spectrometry

FT-IR - Fourier transform infrared spectroscopy

$k_{1}$ - first order rate constant, $\min ^{-1}$

$k_{2}-$ second order rate constant, $\mathrm{g} \cdot \mathrm{mg}^{-1} \cdot \mathrm{min}^{-1}$

$K_{B E T}$ - Brunauer, Emmett and Teller sorption coefficient, $\mathrm{L} \cdot \mathrm{g}^{-1}$

$K_{D R}$ - Dubinin and Radushkevich sorption coefficient, $\mathrm{mol}^{2} \cdot \mathrm{kJ}^{-2}$

$K_{F}$ - Freundlich sorption coefficient, $\mathrm{mg}^{1-1 / \mathrm{n}} \cdot \mathrm{L}^{1 / \mathrm{n}} \cdot \mathrm{g}^{-1}$

$K_{f d}$ - liquid film diffusion rate constant, $\mathrm{mg} \cdot \mathrm{g}^{-1} \cdot \mathrm{min}^{-1}$

$K_{F G J F}$ - Fowler, Guggenheim, Jovanović and Freundlich sorption coefficient, $\mathrm{L} \cdot \mathrm{g}^{-1}$

$K_{F F G}-$ Fumkin, Fowler and Guggenheim sorption coefficient, $\mathrm{L} \cdot \mathrm{g}^{-1}$

$K_{h}$ - Halsey sorption coefficient, $\mathrm{mg}^{\mathrm{n}-1} \cdot \mathrm{g}^{-\mathrm{n}} \cdot \mathrm{L}$

$k_{i}^{h}$ - intra-particle diffusion rate constant, $\mathrm{mg} \cdot \mathrm{g}^{-1} \cdot \mathrm{min}^{-1 / 2}$

$K_{I}$ - Jovanović sorption coefficient, $\mathrm{L} \cdot \mathrm{mg}^{-1}$

$K_{J E}$ - extended Jovanović sorption coefficient, $\mathrm{L} \cdot \mathrm{mg}^{-1}$

$K_{L}$ - Langmuir sorption coefficient, $\mathrm{L} \cdot \mathrm{mg}^{-1}$

$K_{L F}-$ generalized Langmuir and Freundlich sorption coefficient, $\mathrm{L}^{\mathrm{mg}} \mathrm{mg}^{-1}$

$K_{R}$ - Redlich and Peterson sorption coefficient, $\mathrm{L} \cdot \mathrm{g}^{-1}$

$K_{T}$ - Temkin sorption coefficient, ${\mathrm{L} \cdot \mathrm{g}^{-1}}^{-1}$

$K_{T h}$ - Tóth sorption coefficient, $\left(\mathrm{L} \cdot \mathrm{mg}^{-1}\right)^{\mathrm{Th}}$

$L O I$ - loss on ignition, \%

$m$ - sorbent mass, $\mathrm{g}$

$n$ - heterogeneity factor

$P$ - sorption percentage, \%

$P F O$ - pseudo first-order kinetic model

$P S O$ - pseudo second-order kinetic model

$P S D$ - particle size distribution

$q_{0}$ - initial amount of adsorbate in the solution, $\mathrm{mg} \cdot \mathrm{g}^{-1}$

$q_{e}$ - amount of sorbate adsorbed on sorbent at equilibrium (equilibrium sorption capacity), $\mathrm{mg} \cdot \mathrm{g}^{-1}$

$q_{\infty}$ - maximum content of sorbate in sorbent at the sorption equilibrium, $\mathrm{mg} \cdot \mathrm{g}^{-1}$

$q_{t}$ - amount of sorbate adsorbed on sorbent at time $t$, $\mathrm{mg} \cdot \mathrm{g}^{-1}$

$R$ - universal gas constant $\left(8.314 \mathrm{~J} \cdot \mathrm{K}^{-1} \mathrm{~mol}^{-1}\right)$

$R^{2}$ - linear regression coefficient

$S E M$ - scanning electron microscope

$T$ - absolute temperature, $\mathrm{K}$

$t$-sorption time, min or $\mathrm{h}$ $t_{1 / 2}-$ half sorption time, min or $\mathrm{h}$

$T h$ - Tóth heterogeneity factor

$u$ - initial sorption rate, $\mathrm{mg} \cdot \mathrm{g}^{-1} \cdot \mathrm{min}^{-1}$

$V$ - initial volume of the aqueous phase under adsorption, $\mathrm{L}$

$X R D$ - x-ray diffraction

Greek letters

$\alpha$ - Elovich initial sorption rate, $\mathrm{mg} \cdot \mathrm{g}^{-1} \cdot \mathrm{min}^{-1}$

$\alpha_{F G J F}$ - Fowler, Guggenheim, Jovanović and Freundlich constant

$\alpha_{F F G}-$ Fumkin, Fowler and Guggenheim constant

$\beta$ - constant related to the extent of surface coverage and activation energy for chemisorption in the Elovich model, $\mathrm{g} \cdot \mathrm{mg}^{-1}$

$\beta_{R}$ - Redlich and Peterson heterogeneity factor

$\beta_{T}-$ Temkin heat of sorption, $\mathrm{J} \cdot \mathrm{mol}^{-1}$

$\chi^{2}-$ chi-square test

\section{Acknowledgements}

X-ray analysis was made in the Laboratory of Spectrometry, Faculty of Chemistry, Rzeszów University of Technology, 6 Powstanców Warszawy Ave., 35-959 Rzeszów, Poland and was financed from DS budget.

\section{Conflict of Interest}

The authors declare no conflict of interest.

\section{References}

1. SARMA G.K., GUPTA S.S., BHATTACHARYYA K.G. Adsorption of Crystal violet on raw and acid-treated montmorillonite, K10, in aqueous suspension. J. Environ. Manage. 171, 1, 2016.

2. RADWAN N.R.E., HAGAR M., CHAIEB K. Adsorption of crystal violet dye on modified bentonites. Asian J. Chem. 28, 1643, 2016.

3. DING L., ZOU B., GAO W., LIU Q., WANG Z., GUO Y., WANG X., LIU Y. Adsorption of rhodamine-B from aqueous solution using treated rice husk-based activated carbon. Colloids and Surfaces A: Physicochem. Eng. Aspects 446, 1, 2014.

4. ALVER E., METIN A.Ü. Anionic dye removal from aqueous solutions using modified zeolite: Adsorption kinetics and isotherm studies. Chem. Eng. J. 200, 59, 2012.

5. LIU K., LI H., WANG Y., GOU X., DUAN Y. Adsorption and removal of rhodamine $\mathrm{B}$ from aqueous solution by tannic acid functionalized graphene. Colloids and Surfaces A: Physicochem. Eng. Aspects 477, 35, 2015.

6. ANIRUDHAN T.S., RAMACHANDRAN M. Adsorptive removal of basic dyes from aqueous solutions by surfactant modified bentonite clay (organoclay): Kinetic and competitive adsorption isotherm. Process. Saf. Environ. Prot. 95, 215, 2015.

7. AMODU O.S., OJUMU T.V., NTWAMPE S.K., AYANDA O.S. Rapid adsorption of crystal violet onto 
magnetic zeolite synthesized from fly ash and magnetite nanoparticles. J. Encapsu. Adsorp. Sci. 5, 191, 2015.

8. ZHANG X.-F., ZHANG J., LU X. The fluorescence properties of three rhodamine dye analogues: Acridine Red, Pyronin Y and Pyronin B. J. Fluoresc. 25, 1151, 2015.

9. KUMAR R., CHAWLA J., Removal of cadmium ion from water/wastewater by nano-metal oxides: A Review. Water Qual. Expo. Health, 5, 215, 2014.

10. YAACOUBI H., ZIDANI O., MOUFLIH M., GOURAI M., SEBTI S. Removal of cadmium from water using natural phosphate as adsorbent. Procedia Eng. 83, 386, 2014.

11. SZALA B., BAJDA T., MATUSIK J., ZIĘBA K., KIJAK B. BTX sorption on Na-P1 organo-zeolite as a process controlled by the amount of adsorbed HDTMA. Micropor. Mesopor. Mater. 202, 115, 2015.

12. SHEN K., GONDAL M.A. Removal of hazardous rhodamine dye from water by adsorption onto exhausted coffee ground J. Saudi Chem. Soci. 21, 120, 2017.

13. WANG L. Application of activated carbon derived from 'waste' bamboo culms for the adsorption of azo disperse dye: Kinetic, equilibrium and thermodynamic studies. J. Environ. Manage. 102, 79, 2012.

14. MOR S., CHHAVI M.K., SUSHIL K.K., RAVINDRA $\mathrm{K}$. Assessment of hydrothermally modified fly ash for the treatment of methylene blue dye in the textile industry wastewater. Environ. Dev. Sustain. 20, 625, 2018.

15. ASLAM Z., SHAWABKEH R.A., HUSSEIN I.A., AL-BAGHLI N., EIC M. Synthesis of activated carbon from oil fly ash for removal of $\mathrm{H}_{2} \mathrm{~S}$ from gas stream. Appl. Surf. Sci. 327, 107, 2015.

16. DENG H., YU X. Adsorption of fluoride, arsenate and phosphate in aqueous solution by cerium impregnated fibrous protein. Chem. Eng. J. 184, 205, 2012.

17. NARANJO P.M., SHAM E.L., CASTELLON E.R., TORRES SANCHEZ R.M., FARFAN TORRES E.M. Identification and quantification of the interaction mechanisms between the cationic surfactant HDTMA-Br and montmorillonite. Clays and Clay Miner. 61, 98, 2013.

18. MOZGAWA W., JASTRZĘBSKI W., HANDKE M. Cation-terminated structural clusters as a model for the interpretation of zeolite vibrational spectra. J. Mol. Struct. 792, 163, 2006

19. SOČO E., KALEMBKIEWICZ J. Comparison of adsorption of $\mathrm{Cd}(\mathrm{II})$ and $\mathrm{Pb}(\mathrm{II})$ ions on pure and chemically modified fly ashes. Chem. Proc. Eng. 37, 215, 2016.

20. RANI S., AGGARWAL M., KUMAR M., SHARMA S., KUMAR D. Removal of methylene blue and rhodamine B from water by zirconium oxide/graphene. Water Sci. 30, $51,2016$.

21. CAN M. Studies of the kinetics for rhodium adsorption onto gallic acid derived polymer: the application of nonlinear regression analysis. Acta Phys. Pol. A, 127, 1308, 2015.

22. SHEELA T., ARTHOBA NAYAKA Y. Kinetics and thermodynamics of cadmium and lead ions adsorption on $\mathrm{NiO}$ nanoparticles. Chem. Eng. J. 191, 123, 2012.

23. LI H., HUANG G., AN C., ZHANG W. Kinetic and equilibrium studies on the adsorption of calcium lignosulfonate from aqueous solution by coal fly ash. Chem. Eng. J. 200, 275, 2012.

24. SHEELA T., ARTHOBA NAYAKA Y., VISWANATHA V., BASAVANNA S., VENKATESHA T.G. Kinetics and thermodynamics studies on the adsorption of $\mathrm{Zn}(\mathrm{II})$,
$\mathrm{Cd}(\mathrm{II})$ and $\mathrm{Hg}$ (II) from aqueous solution using zinc oxide nanoparticles. Powder Technol. 217, 163, 2012.

25. MOHD HAFIZUDDIN M., SITI ROZAIMAH S. A., HASSIMI ABU H., REEHAN ADNEE A. R., SITI NUR H.A.B., NURIZZATI I., MOHD IZUAN E. H. Adsorption isotherm and kinetic studies of pentachlorophenol removal from aqueous solution onto coconut shell-based granular activated carbon. J. Environ. Sci. Technol. 11, 68, 2018.

26. TARAWOU T., YOUNG E. Intraparticle and liquid film diffusion studies on the adsorption of $\mathrm{Cu}^{2+}$ and $\mathrm{Pb}^{2+}$ ions from aqueous solution using powdered cocoa. International Research Journal of Engineering and Technology (IRJET), 2, 236, 2015.

27. LIU X., ZHANG L. Removal of phosphate anions using the modified chitosan beads: Adsorption kinetic, isotherm and mechanism studies. Powder Technol. 277, 112,2015

28. NETHAJI S., SIVASAMY A., MANDAL B. Adsorption isotherms, kinetics and mechanism for the adsorption of cationic and anionic dyes onto carbonaceous particles prepared from Juglans regia shell biomass. Int. J. Environ. Sci. Technol. 10, 231, 2013.

29. JEPPUAT G.P., CLEMENT T.P. A modified LangmuirFreundlich isotherm model for simulating $\mathrm{pH}$-dependent adsorption effects. J. Cont. Hydrology. 129, 46, 2012.

30. BEDIN K.C., MARTINS A.C., CAZETTA A.L., PEZOTI O., ALMEIDA V.C. KOH-activated carbon prepared from sucrose spherical carbon: Adsorption equilibrium, kinetic and thermodynamic studies for methylene blue removal. Chem. Eng. J. 286, 476, 2016.

31. GHANBARI PAKDEHI S., ALIPOUR M. Adsorption of $\mathrm{Cr}(\mathrm{III})$ and $\mathrm{Mg}(\mathrm{II})$ from hydrogen peroxide aqueous solution by amberlite IR-120 synthetic resin. Iran. J. Chem. Chem. Eng. 32, 49, 2013.

32. NAGY B., MÂNZATU C., MĂICĂNEANU A., INDOLEAN C., BARBU-TUDORAN L., MAJDIK C. Linear and nonlinear regression analysis for heavy metals removal using Agaricus bisporus macrofungus. Arabian J. Chem. 10, 3569, 2017.

33. FOO K.Y., HAMEED B.H. Mesoporous activated carbon from wood sawdust by $\mathrm{K}_{2} \mathrm{CO}_{3}$ activation using microwave heating. Bioresource Technol. 111, 425, 2012.

34. FOO K.Y., HAMEED B. H. Preparation, characterization and evaluation of adsorptive properties of orange peel based activated carbon via microwave induced $\mathrm{K}_{2} \mathrm{CO}_{3}$ activation. Bioresource Technol. 104, 679, 2012.

35. AICHOUR A., ZAGHOUANE-BOUDIAF H. Highly brilliant green removal from wastewater by mesoporous adsorbents: Kinetics, thermodynamics and equilibrium isotherm studies. Microchem. J. 146, 1255, 2019.

36. AMIN M.T., ALAZBA A.A., SHAFIQ M. Adsorptive removal of reactive black 5 from wastewater using bentonite clay: Isotherms, kinetics and thermodynamics. Sustainability, 7, 15302, 2015.

37. BACCAR R., BLÁNQUEZ P., BOUZID J., FEKI M., ATTIYA H., SARRÀ M. Modeling of adsorption isotherms and kinetics of a tannery dye onto an activated carbon prepared from an agricultural by-product. Fuel Process. Technol. 106, 408, 2013.

38. GHOLITABAR S., TAHERMANSOURI H. Kinetic and multi-parameter isotherm studies of picric acid removal from aqueous solutions by carboxylated multiwalled carbon nanotubes in the presence and absence of ultrasound. Carbon Lett. 22, 14, 2017. 